\title{
The Use of Subsidence to Estimate Carbon Loss from Deforested and Drained Tropical Peatlands in Indonesia
}

\author{
Gusti Z. Anshari ${ }^{1,2}{ }^{\circledR}$, Evi Gusmayanti ${ }^{1,3}$ and Nisa Novita ${ }^{4, *}$ \\ 1 Magister of Environmental Science, Universitas Tanjungpura, Pontianak 78124, Indonesia; \\ gzanshari@live.untan.ac.id (G.Z.A.); evi.gusmayanti@faperta.untan.ac.id (E.G.) \\ 2 Soil Science Department, Universitas Tanjungpura, Pontianak 78124, Indonesia \\ 3 Agrotechnology Department, Universitas Tanjungpura, Pontianak 78124, Indonesia \\ 4 Yayasan Konservasi Alam Nusantara, DKI Jakarta 12160, Indonesia \\ * Correspondence: nisa.novita@tnc.org
}

Citation: Anshari, G.Z.; Gusmayanti, E.; Novita, N. The Use of Subsidence to Estimate Carbon Loss from Deforested and Drained Tropical Peatlands in Indonesia. Forests 2021, 12, 732. https://doi.org/10.3390/ f12060732

Academic Editors: Kanako Morita, Makoto Ehara and Joni Jupesta

Received: 28 April 2021

Accepted: 27 May 2021

Published: 4 June 2021

Publisher's Note: MDPI stays neutral with regard to jurisdictional claims in published maps and institutional affiliations.

Copyright: (c) 2021 by the authors. Licensee MDPI, Basel, Switzerland. This article is an open access article distributed under the terms and conditions of the Creative Commons Attribution (CC BY) license (https:/ / creativecommons.org/licenses/by/ $4.0 /)$.

\begin{abstract}
Drainage is a major means of the conversion of tropical peat forests into agriculture. Accordingly, drained peat becomes a large source of carbon. However, the amount of carbon (C) loss from drained peats is not simply measured. The current $C$ loss estimate is usually based on a single proxy of the groundwater table, spatially and temporarily dynamic. The relation between groundwater table and $\mathrm{C}$ emission is commonly not linear because of the complex natures of heterotrophic carbon emission. Peatland drainage or lowering groundwater table provides plenty of oxygen into the upper layer of peat above the water table, where microbial activity becomes active. Consequently, lowering the water table escalates subsidence that causes physical changes of organic matter $(\mathrm{OM})$ and carbon emission due to microbial oxidation. This paper reviews peat bulk density (BD), total organic carbon (TOC) content, and subsidence rate of tropical peat forest and drained peat. Data of BD, TOC, and subsidence were derived from published and unpublished sources. We found that BD is generally higher in the top surface layer in drained peat than in the undrained peat. TOC values in both drained and undrained are lower in the top and higher in the bottom layer. To estimate carbon emission from the top layer $(0-50 \mathrm{~cm})$ in drained peats, we use BD value 0.12 to $0.15 \mathrm{~g} \mathrm{~cm}^{-3}$, TOC value of $50 \%$, and a $60 \%$ conservatively oxidative correction factor. The average peat subsidence is $3.9 \mathrm{~cm} \mathrm{yr}^{-1}$. The range of subsidence rate per year is between 2 and $6 \mathrm{~cm}$, which results in estimated emission between 30 and $90 \mathrm{tCO}_{2} \mathrm{e} \mathrm{ha}^{-1} \mathrm{yr}^{-1}$. This estimate is comparable to those of other studies and Tier 1 emission factor of the 2013 IPCC GHG Inventory on Wetlands. We argue that subsidence is a practical approach to estimate carbon emission from drained tropical peat is more applicable than the use of groundwater table.
\end{abstract}

Keywords: bulk density; carbon loss; drained peat; organic carbon; peat forest; subsidence

\section{Introduction}

Carbon loss in drained peat occurs globally, particularly in tropical regions. Drainage typically occurs during peat swamp forest conversion to agricultural lands, primarily for oil palm and acacia plantations. Drainage involves lowering the groundwater table, thus providing an aerobic environment for the cultivation of non-native plant species of the tropical peat. Consequently, the peat decomposition rate accelerates due to microbial oxidation of organic matters (OMs) in drained peats [1-5]. Currently, the measurement of the groundwater table is the most acceptable model for estimating carbon loss in drained peat [4,6-10]. However, research has shown that the groundwater table does not always positively correlate with carbon emission [11,12]. Other factors, such as soil moisture, soil $\mathrm{pH}$, and fertilizer application [6,13-15], are significant predictors in estimating carbon loss from drained peat soil. Unfortunately, continuous monitoring of groundwater table and carbon emission is not practical in the tropical peatlands in Southeast Asia due to expensive automatic chambers, lack of electrical power in remote peat area, and lack of skilled human 
resources on peatlands carbon accounting. Therefore, there is a need to measure carbon loss that can practically and accurately be implemented in tropical peatlands in Southeast Asia.

We propose a robust and straightforward approach to estimate carbon loss in drained peat, using a yearly subsidence rate. This approach is more practical than using a groundwater table as a predictor, which is naturally dynamic and needs to be continuously monitored. The installation of a peat subsidence monitoring tool is relatively easy, using a sturdy subsidence pole implanted to mineral substratum underneath peat. The measurement of subsidence is monitored every three or six months. The material for constructing a subsidence pole is cheap and widely available, i.e., using strong metal or high-quality PVC poles.

\section{Methods}

We collected both published and unpublished data of BD and TOC from drained and undrained peats. We used published subsidence rate data. Locations of these studies cover both coastal and inland peats in Kalimantan, including Sarawak, northern Borneo, and the eastern coast of Sumatra. Bulk density and TOC data representing undrained peats are derived from Lake Siawan, West Kalimantan; Maludam National Park, northern Borneo; Sebangau National Park, Central Kalimantan; and Batang Hari River, Jambi Province, Sumatra. Bulk density and TOC data representing drained peats are derived from Rasau Jaya peat complex, West Kalimantan; Jabiren, Central Kalimantan; and Tanjung Jabung Barat, Jambi. We compiled a big data set of BD and TOC in Table S1. In addition, data subsidence is derived from published studies in Riau, Jambi, West Kalimantan, Central Kalimantan, Aceh, and Western Johor. Figure 1 shows research sites where bulk density (BD), total organic carbon (TOC), and subsidence rates were compiled and analyzed.

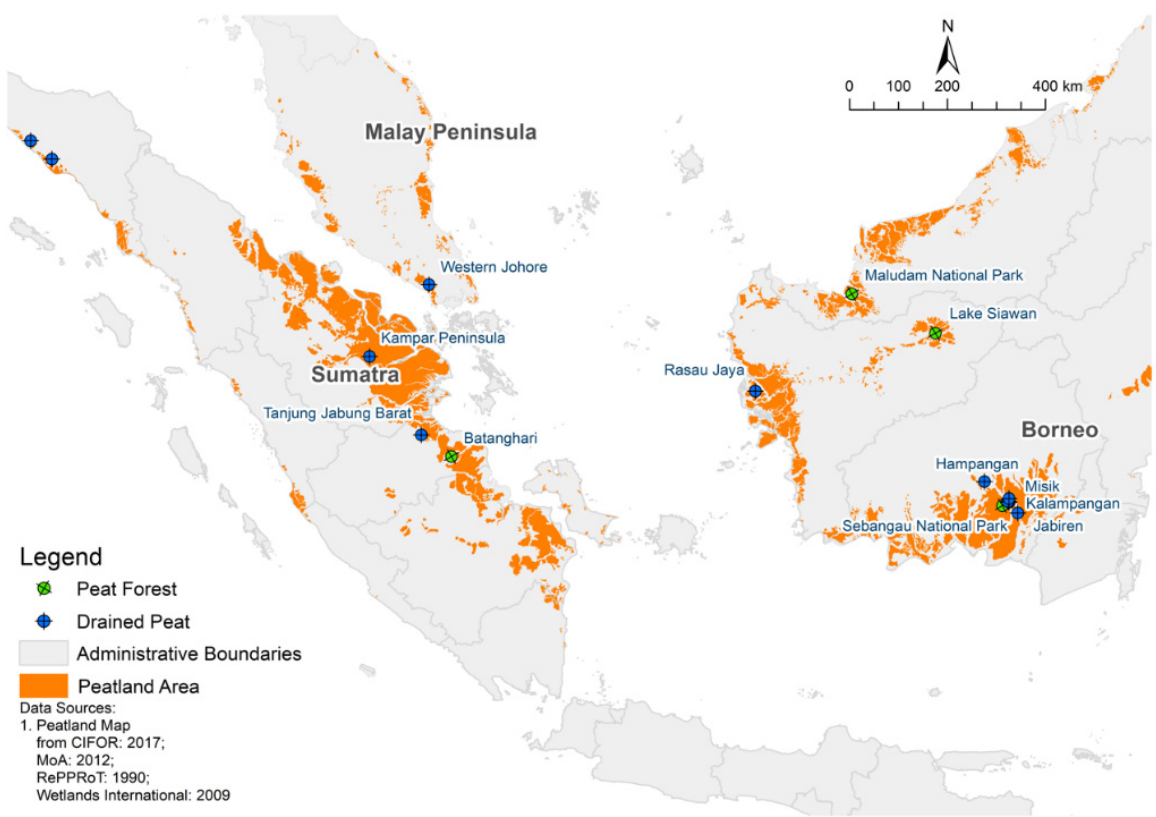

Figure 1. Locations of drained peats for agriculture and undrained peat forests where data on bulk density (BD), total organic carbon (TOC), and subsidence rates were compiled and analyzed in this review. Please note that status of peat forests is presently subject to change to drained peats, i.e., Batang Hari, Jambi and Sebangau National Park, Central Kalimantan.

Sample depth intervals used to measure BD and TOC varied from one study to another. We regroup the sample depth at $50 \mathrm{~cm}$ intervals to compare these data from one study to another. We analyzed 308 samples of drained peat, and these data cover the top surface $50 \mathrm{~cm}$ until $200 \mathrm{~cm}$ depth. We analyzed 259 samples in the undrained peat forest, covering up to $300 \mathrm{~cm}$ depth. Profiles of BD and TOC are pr Pearson correlation and scatter plot are 
utilized to explain the correlation between BD and TOC in the drained and deforested site and the undrained peat forest.

Despite the variation of subsidence rate data, we compiled subsidence data post ten years of canal construction. We aim to analyze only the subsidence rate in drained peats, which have been converted into agricultures since more than ten years ago. Land uses covering subsidence data are Acacia plantation, oil palm, rubber plantation, and other cultivated crops. Based on BD, TOC, and subsidence rate, we calculate carbon (C) loss due to drainage and land-use change (See Equation (1) in Section 8).

\section{Distribution, Vegetation Formation and Uniqueness of Tropical Peat}

Peat occurs in all climatic zones, from tropic to arctic [16], and the area of total global peat is approximately 423.2 million ha [17]. Food and Agriculture Organization [18] estimated the range of global peat is between 325 to 375 million ha. However, these peats were primarily found in the boreal, sub-artic, and arctic regions of the Northern Hemisphere, temperate region of Western Europe, northern Scandinavia, and West Siberia. Some peats may also be found in the cool mountain [18-20]. Only about $10 \%$ of peats are located in tropical regions of South America, Africa, and Southeast Asia [18,21-24]. The tropical peats in Southeast Asia were initially determined to be the largest, about 25 million ha (Mha), and were mostly located in Sumatra, Kalimantan, and Papua [22,23,25]. Gumbricht et al. [26] challenged the extent of tropical peat. They suggested that the most extensive tropical peat area is located in America, up to $63 \mathrm{Mha}$, and the total tropical peat was estimated to be 150 Mha instead. Conservative estimates of tropical peats range from 36 to 47 Mha $[21,22]$.

The tropical peat forest ecosystem is special and unique. Tree species in tropical peat forests have some similarities to tree species in dipterocarp forest on drylands. Most tree species have a particular organ to cope with an inundated environment. Many trees in this tropical swamp have pneumatophores [27]. In contrast, other trees uniquely adapt to high groundwater tables by growing on the raised peat surface (hummocks or ridge), creating aerobic and fertile rooting zone [28]. The lower peat surface is called slough or hollows, which are commonly water-logged. Lampela et al. [27] conclude that the formation of microtopography of tropical peat is through random processes. It was hypothesized that the varying accretion rates of OMs in ridge and slough play a significant role in forming the undulating surface microtopography. Large trees are predominantly located on the ridge (hummocks), which provide the trees with the added benefit of more nutrients and oxygen than in the slough $[28,29]$. The availability of oxygen in hummocks supports the growth of plants and speeds the decomposition of OMs [29]. Large trees tend to occupy the ridges, while other adapting water-logged vegetation tends to occupy the slough [27].

Organic matters that form tropical peats are derived from mangrove trees, freshwater swamp trees, heath forests, grass, and sedge ferns. A variety of vegetation formations occurs in a tropical peat swamp in Southeast Asia. For example, Anderson [30] and Anderson and Muller [31] described the six vegetation formations in the coastal peat dome in Northern Sarawak. These vegetation formations in tropical peat domes show unique adaptation capabilities of peat swamp vegetation to changes of peat thickness. Tall and small-diameter trees in the central peat dome area better adapt to the less fertile peat than the mixed and large trees in the shallow and regularly inundated peat area. However, episodic dry spells associated with El Niño may cause a substantial drop of water storage in the peat dome, leading to a drop of water storage in the central peat dome. This explains why the stunted and low pole forest is predominantly in the center of the peat dome. The colonization of Nephentes is common in the peat region, which is deficient in nitrogen and frequently suffers from water stress.

In reality, the vegetation zonation in every peat dome seems to adapt to local conditions. Page et al. [32] report the diversity of vegetation formations in Sebangau peat dome, Central Kalimantan. Low pole and tall interior forests are typically found in the deep peat $(8-10 \mathrm{~m})$. Mixed dipterocarp forests occur in shallow peat $(2-3 \mathrm{~m})$. The riverine forests 
occur in the very shallow peat area (about 1-1.5 m). In Sumatra, Kuniyasu and Tetsuya [33] described some similarities between the vegetation associations in tropical peat forests in the riparian area and the tidal and deltaic peats in the Kerumutan River, eastern Sumatra.

Tropical peat swamp contains rich and diverse flora, yet they are not well valued. Lucrative timber species such as Shorea blangeran, Dyera polyphilla, and Gonystylus bancanus are intensively logged, causing deforestation and habitat destruction. The removal of vegetation in the tropical peat swamp forest causes the depletion of OMs, which are necessary for maintaining peat accumulation. In addition to a continuous supply of OMs, the waterlogged environment that controls the rate of OM decays is a prerequisite for peat formation in the tropic. High percentages of aromatic chemicals in tropical peats may inhibit the rapid decomposition rate in a warm climate [21,34]. Peat accumulation does not occur when the supply of OM input is either intermittent or limited, which leads to a higher decomposition rate of dead OMs compared to the delivery rate of freshly dead OM to the peat-forming site. Therefore, under anthropogenic disturbances, such as deforestation, drainage, and fires, peat accumulation stops [35] and, consequently, peats act as a source of carbon to the environment [36-38].

\section{Selected Peat Properties Affecting Carbon Stock}

Based on soil taxonomy, peat is commonly known as either Histosols [18,39], or Organosols [40]. The content of elemental, organic carbon in OMs determines physical, chemical, and biological properties of Histosols. According to Soil Survey Staff [39], the elemental organic carbon in Histosols is greater than $12 \%$. The thickness of OMs is minimum in the range of $40 \mathrm{~cm}$ to $60 \mathrm{~cm}$, depending on the rate of peat decomposition. Fibric peat must have at least $60 \mathrm{~cm}$ thick of continuous OMs, and both hemic and sapric peats must have $40 \mathrm{~cm}$ thick OMs. In Indonesia, the minimum thickness of OMs is $50 \mathrm{~cm}$ [40]. Peaty soil has less than $50 \mathrm{~cm}$ of OMs. The amount of OMs in tropical peat soil range between $65 \%$ and $99 \%$ [23,41-43]. This OM content plays a vital role in water storage. Under extreme dryness conditions, $\mathrm{OM}$ is not capable of absorbing water (hydrophobic). Healthy peat is hydrophilic, permanently bonding with water through hydrogen bonds (carboxyl and hydroxyl groups). Hydrophobic peat has more non-polar aromatic compounds than polar aliphatic compounds [12]. The loss of water retention capability of peat soil results in hydrophobic peat, particularly the acrotelm layer, which makes the peat soil susceptible to fire $[12,44]$. Furthermore, fibric and hemic peats are less likely to be stable than sapric peat due to the decomposition of aliphatic organic compounds in newly deposited OMs [45].

Bulk density of tropical peat is very low, ranging from $0.04 \mathrm{~g} \mathrm{~cm}^{-3}$ to $0.30 \mathrm{~g} \mathrm{~cm}^{-3}[21,43,46]$. The average bulk density values of fibric, hemic, and sapric peats are $0.09 \mathrm{~g} \mathrm{~cm}^{-3,} 0.12 \mathrm{~g} \mathrm{~cm}^{-3}$, and $0.20 \mathrm{~g} \mathrm{~cm}^{-3}$. An increase in bulk density of peat soil is irreversible due to physical compaction and consolidation of OMs. Drainage significantly causes an increase in bulk density and is associated with the reduction of elemental organic carbon content [47]. An increase of $0.01 \mathrm{~g} \mathrm{~cm}^{-3}$ in bulk density causes a decrease of $0.6 \mathrm{mg} \mathrm{C} \mathrm{g}^{-1}$ [48]. Therefore, an increase in bulk density indicates peat subsidence, which is directly associated with carbon emission to the atmosphere $[1,4,8,10]$, and water discharge [49-52].

\section{Peat Degradation}

Deforestation reduces the supply of OM, a parent material for peat formation. The removal of large commercial trees due to logging causes the collapse of ridges, where large trees commonly live. After logging, the logged-over peat swamp forest may suffer from vegetation degradation and the change in surface microtopography that regulate the spatial distribution of vegetation assemblages in tropical peat swamp forests. Moreover, timber harvesting has significant impacts on the continuity of OM delivery, consequently inhibiting the development and growth of native vegetation in tropical peat swamp forests. The initial process that leads to the development of native vegetation into several vegetation assemblages under deficient nutrients and an unfavorable environment in the peat swamp 
forest is currently unknown. In general, vegetation formations in the tropical peat habitat are circular and singular, showing adaptation to one peat habitat relative to another peat habitat [53]. Figure 2 illustrates anthropogenic disturbances that cause peat subsidence in tropical peat swamp forests. Subsidence is globally considered as a major criterium of peat degradation in drained peatland.

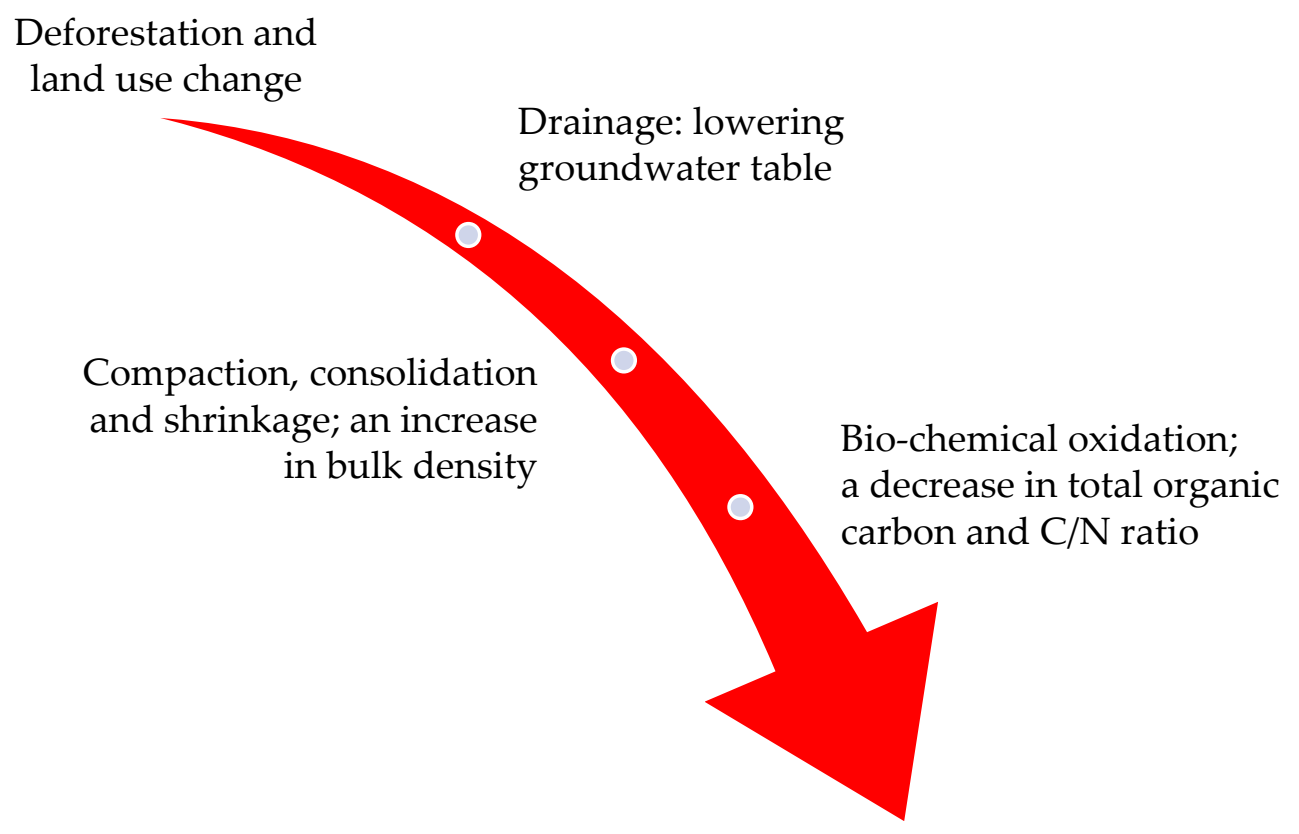

Peat subsidence

Figure 2. The relationship between anthropogenic disturbances on tropical peat forest ecosystem and peat subsidence.

Drainage causes severe degradation because of the change of the hydrological cycle and hence water balance. In a natural state, peatland acts as an important wetland that stores water. Drainage leads to groundwater table depletion, withdrawn by an increase in water discharge and evaporation from the open canopy or deforested peat. Anthropo-genically drained peat leads to rapid subsidence and the change of peat properties. Drainage triggers rapid decomposition, which is caused by the breakdown of phenolic compounds under aerobic conditions [54,55]. The significant impact of drainage on the loss of peat surface or subsidence in drained peat is widely recorded [1,2,8,56-62].

\section{Subsidence}

In a natural state, the groundwater table in peat is always high. The primary factors that determine water storage in peats are rainfall, evapotranspiration, and water discharge. When considering the hydrological property of peatlands, their thickness, decomposition, type of peat landscape, land cover, hydraulic conductivity, and drainage canal are some of the most relevant factors that control the property. Moreover, depending on the location, river tides control the groundwater table in coastal peat. Meanwhile, forested land cover on tropical peat forests protects direct exposure of peat surfaces from sunlight and controls the rate of evaporation. During a period of seasonal drought, the groundwater table significantly declines, but the peat surface is still able to maintain its moisture and stays wet. Drained and deforested peat suffers from water deficit and loss of particle of OM, which makes peatlands prone to irreversible dryness. Furthermore, lowering the groundwater table increases oxygen availability for peat decomposition, hence increasing carbon emission. Consequently, drained peats suffer from water deficit during droughts and are, therefore, easily ignited, which leads to more carbon emissions.

Peat under anthropogenically drainage disturbance always subsides due to both physical and chemical changes of OMs. Therefore, compaction and consolidation of 
particles in OMs are direct consequences of anthropogenic disturbances on peat soil. This change leads to pore space reduction and bulk density increase. Moreover, oxidation causes a decline of carbon concentration in the peat matrix, and this chemical removal process in the peat surface contributes to carbon release. The rate of peat subsidence is initially high in the first year of drainage, and then the rate stabilized in the following years. The average rate of peat subsidence in Southeast Asia is reported to be around $2.2 \mathrm{~cm}$ per year [63]. However, Evans et al. [64] reported that the average rate of peat subsidence in Acacia plantation on tropical peat in Sumatra might reach as high as $4.3 \mathrm{~cm}$ per year.

To combat the loss of carbon, managing a high water table and keeping peatland wet is the only practice that would decline the present peat subsidence by 20 to $30 \%[4,64,65]$. Thermal subsidence due to fire is varied mainly due to differences in fire regimes and the capacity of water retentions in peat. Based on a remote sensing analysis, Khakim et al. [66] reported that the 2015 fire caused drained peat in South Sumatra to subside in the range of $12 \mathrm{~cm}$ to $250 \mathrm{~cm}$, but this result still needs to be validated. Wösten et al. [8] propose that every $10 \mathrm{~cm}$ water drainage results in a $0.4 \mathrm{~cm}$ subsidence rate per year in tropical peat in Sarawak, Malaysia. However, drainage does not only cause groundwater table withdrawal, but also it causes changes in the physical, chemical, and biological properties of peat. An increase in bulk density is commonly observed post drainage as OMs shrunk and became more compact and consolidated. Therefore, Darmawan et al. [67] suggested that an increase in bulk density is not a good indicator to determine compaction because of the fluctuation of moisture contents. Seasonally, OMs swell during the wet season, and, in contrast, OMs shrink during the dry season. To take these characteristics into account, an average of bulk density in both seasons is considered appropriate to assess peat compaction based on an increase in bulk density value caused by drainage [68].

Researchers have also considered plant species as a predictor for carbon emission. However, this factor is not preferred because, in a natural state, tropical peat forests consist of a variety of vegetation formations. Microbial activities control rates of peat decomposition, while the vegetation functions as a supplier of OMs. Carlson et al. [69] reviewed a positive relation between long-term groundwater table $(\sim 20-110 \mathrm{~cm})$ and carbon loss from plantations on drained tropical peat. The model suggests that an average groundwater table of $70 \mathrm{~cm}$ would result in total emission in the range 18 to $22 \mathrm{tC} \mathrm{ha}^{-1} \mathrm{yr}^{-1}$, with an average of $20 \mathrm{tC} \mathrm{ha}^{-1} \mathrm{yr}^{-1}$. This model uses a subsidence approach to estimate the amount of carbon emission. For comparison, the IPCC default values of total emission from oil palm and acacia plantations on peat are $11 \mathrm{tC} \mathrm{ha}^{-1} \mathrm{yr}^{-1}$ and $20 \mathrm{tC} \mathrm{ha}^{-1} \mathrm{yr}^{-1}$ [70], respectively. Carlson et al. [69] concluded that vegetation species do not significantly affect the total emission and suggest that total carbon emissions from oil palm (Elaeis guineensis) and acacia timber (Acacia crassicarpa) plantations are indifferent. However, this conclusion does not yet cover vegetable and horticultural agricultures on tropical peatland. Jamaludin et al. [71] reported a large carbon emission from small-scale agriculture from drained peats in West Kalimantan. Khasanah and Noordwijk [72] and Wakhid et al., [56] also reported a large carbon emission from small-scale agricultures of rubber (Hevea brasiliensis), coffee (Coffea liberica), betel nut (Areca catechu), and mixed coconut (Cocos nucifera) garden. Nurzakiah et al. [12] reported relatively low carbon emission from rubber plantation intercropping with pineapple, which was $6 \mathrm{tC} \mathrm{ha}^{-1} \mathrm{yr}^{-1}$, and from traditional rubber plantations, which was $5 \mathrm{tC} \mathrm{ha}^{-1} \mathrm{yr}^{-1}$. Low emission values in the agricultural land can be attributed to the natural hydrophobicity of selected aromatic organic compounds such as lignin [21], in that when the tropical peat soil particles are not dissolved in water and the particles become recalcitrant for biological decomposition $[15,73]$. This finding seems to confirm the conclusion that plant species are not a good predictor for estimating carbon emission from drained peats in the tropic.

Other factors that influence carbon emission from drained tropical peats are rarely investigated. These include OM decomposability, surface microtopography, fertilizer application, soil moisture, and soil and air temperatures. Knowledge of chemical variations that affect carbon emission in tropical peat is very important for understanding how carbon 
emits from peat soil [74]. However, the chemical composition of OMs in tropical peat is very diverse as the origin of tropical peat is derived from various swamp tree species, which makes chemical analysis challenging.

The micro-topography of the peat surface is primarily composed of hummocks and hollows $[28,75]$. Hummocks play a significant role in providing a rooting zone, a source of total $\mathrm{CO}_{2}$ emission. Either regular or permanent inundation characterizes hollows or depression lenses. Irregular patterns of hummocks and hollows in tropical peat surfaces influence the unique distribution of tree diversity [28]. Anaerobic condition supports methanogen activity to produce $\mathrm{CH}_{4}$ under water-saturated peat surface [76]. In general, depending on groundwater table depth, the main source of carbon emission is from $0-30 \mathrm{~cm}$ peat surface [74].

Degradation of tropical peat forests also occurs in Asia, Africa, and America. The degree of tropical peat degradation is larger in Southeast Asia than those in Africa and America. Factors that control this degradation are remoteness of the location, human population density, law enforcement, and government policies on the protection of tropical peats [77]. Overall, anthropogenic drainage leads to the degradation of tropical peat forests, which change the ecological function from a carbon sink into a source [37,62,78-80]. Peats degradation around the world is predicted to act as a carbon source under global warming [37,81-83]. Figure 3 shows a PVC subsidence pole and anthropogenic disturbances on tropical peats.

(a)

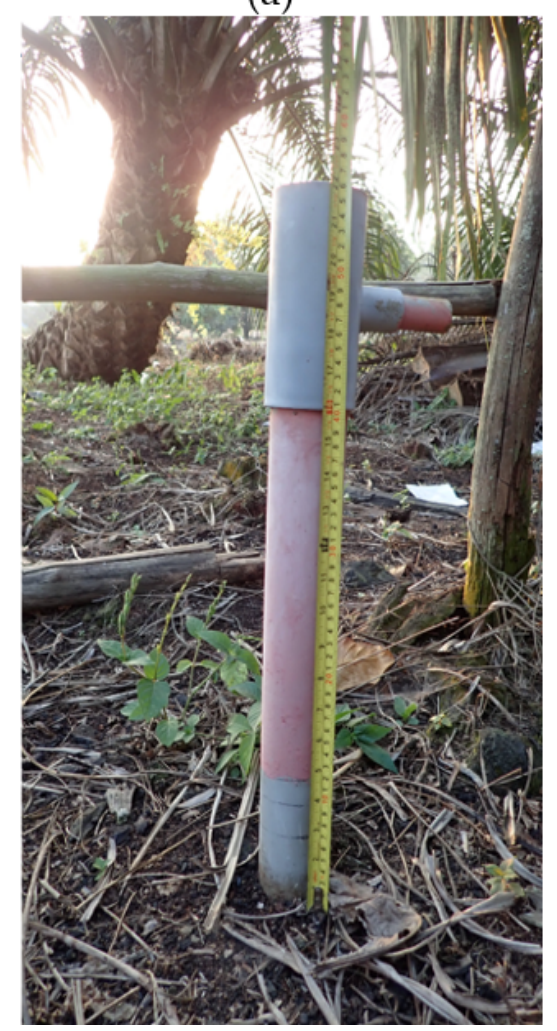

(b)

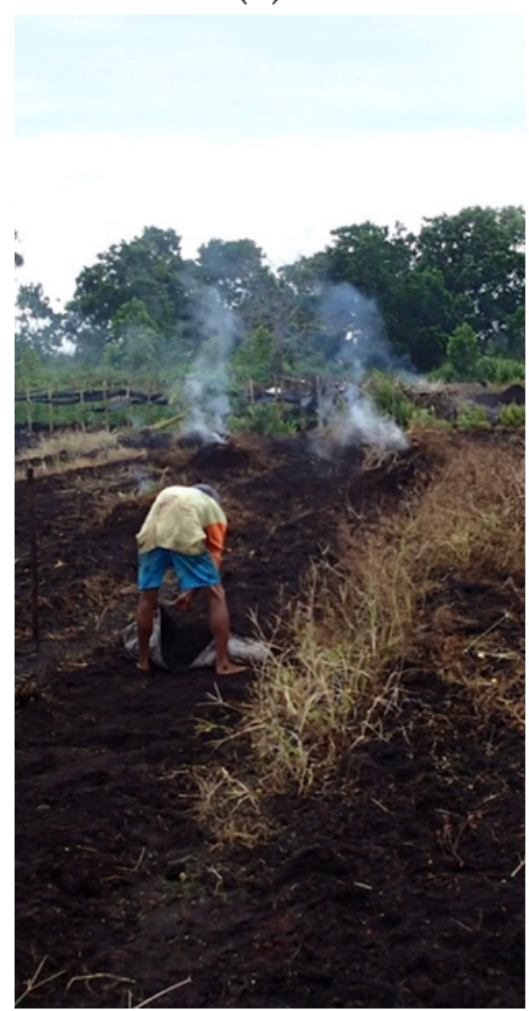

(c)

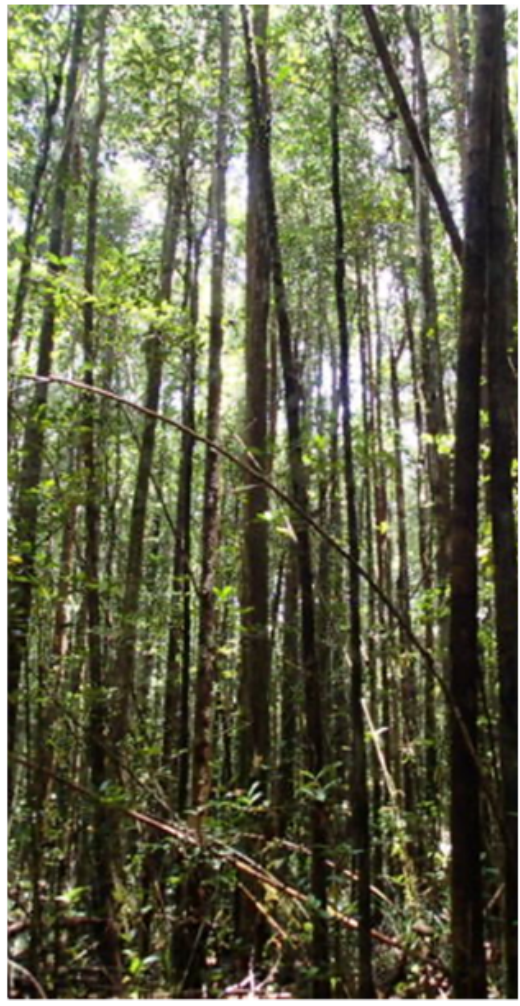

Figure 3. A PVC (Polyvinyl chloride) subsidence pole at an oil palm plantation (a); Slash and burnt farming on peat (b); and a logged-over- peat forest in the upper Kapuas River, West Kalimantan Province, Indonesia (c). Photos: Gusti Anshari.

Drainage provides ample oxygen into the acrotelm, which is an upper layer above the groundwater table. The removal of water in this layer causes OMs to shrink, compact, and consolidate. As a result, most pore spaces are filled with oxygen, which provides a favorable environment for biological decomposition. Drainage directly erodes the height of the peat surface, which is commonly used as a good predictor of carbon loss. Peat surface subsidence is divided into primary and secondary subsidence. Compaction and consolidation are 
initially led to physical changes, but both processes may reduce peat volume or shrinkage. However, this primary subsidence does not lead to carbon loss. Subsidence processes continue into secondary, which leads to oxidation of OMs or persistent carbon emission post drainage. The estimated oxidation caused by peat subsidence range from 60 to $75 \%[4,8,61,84]$. The rate of peat subsidence is initially between 20 to $50 \mathrm{~cm}$ per year in the first or second year of drainage [8]. Then, the rate of peat subsidence reduces into 4 to $6 \mathrm{~cm}$ per year $[4,8,64]$. Finally, the rate of peat subsidence becomes stable at 1.5 to $2 \mathrm{~cm}$ per year $[8,63]$. It is estimated that post ten years of deforestation and drainage, the Sebangau peatland in Central Kalimantan suffered from total compaction in the range 2 to $4 \mathrm{~m} \mathrm{[68],}$ causing a substantial reduction of peat depth.

Peat subsidence caused by fire is not easily studied as fire consumes both vegetation biomass and the dry fraction of OMs in peat. Peat fire is known as a smoldering fire that does not cause complete oxidation. Peat fires are commonly recurrent, emitting different amounts of carbon each fire event [85], and oxidation of OMs might continue post-fire occurrences [86]. Methane $\left(\mathrm{CH}_{4}\right)$ emission might increase if the post-fire groundwater table becomes sufficiently high and the peatland area is inundated [87].

The current model to estimate carbon loss from drained tropical peat uses a subsidence approach based on the groundwater table as a proxy of peat oxidation. Subsidence is divided into physical, biological, and thermal subsidence (See Table 1). Wösten et al. [8,59] firstly introduced this model, and the model becomes widely used and popular after the publication of Hooijer et al., [4,88]. Further, Wösten et al. [59] explained that the groundwater level at $40 \mathrm{~cm}$ from peat surface is critical for preventing drained peatland from fires. In sum, peat subsidence is unavoidable if a drainage canal is constructed.

Table 1. Subsidence and impact.

\begin{tabular}{lll}
\hline \multicolumn{1}{c}{ Subsidence } & \multicolumn{1}{c}{ Category } & \multicolumn{1}{c}{ Impact } \\
\hline Physical & Compaction, consolidation and shrinkage & Bulk density increase, and decrease in volumetric water content \\
Biological & Microbial oxidation/decomposition & Carbon emission/loss to atmosphere and water \\
Thermal & Smoldering fire & Haze pollution and carbon loss to atmosphere \\
\hline
\end{tabular}

\section{Profiles of Bulk Density and Total Organic Carbon}

Peat thickness, BD, and TOC are important parameters to estimate carbon stock in peat soil. Carbon density (CD) is a product of BD times TOC. This sub-section presents distribution $\mathrm{BD}$ and TOC according to peat thickness and Pearson correlation between $\mathrm{BD}$ and TOC in the undrained peat forest and drained peatland.

Figure $4 \mathrm{a}$ shows that BD in the undrained peat forest is not statistically different at different peat thicknesses. The pattern shows a slight increase following an increase in peat thickness. The range of BD in the top layer $(0-50 \mathrm{~cm})$ is 0.09 to $0.13 \mathrm{~g} \mathrm{~cm}^{-3}$. The overall mean BD in this site is $0.12 \pm 0.06 \mathrm{~g} \mathrm{~cm}^{-3}$. On the other hand, Figure $3 \mathrm{~b}$ shows a declining pattern of $\mathrm{BD}$ following peat thickness in the drained peat. High $\mathrm{BD}$ in the top layer $(0-50 \mathrm{~cm})$ indicates peat compaction. The range of $\mathrm{BD}$ in this top layer is 0.12 to $0.15 \mathrm{~g} \mathrm{~cm}^{-3}$, and the range of BD in the bottom layer $(150-200 \mathrm{~cm})$ is 0.08 to $0.09 \mathrm{~g} \mathrm{~cm}^{-3}$. The overall mean BD in the drained peat is $0.11 \pm 0.07 \mathrm{~g} \mathrm{~cm}^{-3}$.

The pattern of TOC in Figure 5 shows a similar story to that of BD. Low TOC concentrations are observed in the top peat layer in both undrained and drained peat sites. The TOC values in drained and undrained peat are $49 \%$ to $52 \%$ and $50 \%$ to $52 \%$, respectively. The range of TOC in the bottom layer in drained and undrained peat is $54 \%$ to $56 \%$ and $52 \%$ to $53 \%$, respectively. These observations suggest that peat decomposition occurs in both drained and undrained peat, particularly in the top layer subject to the natural fluctuation of the groundwater table. 


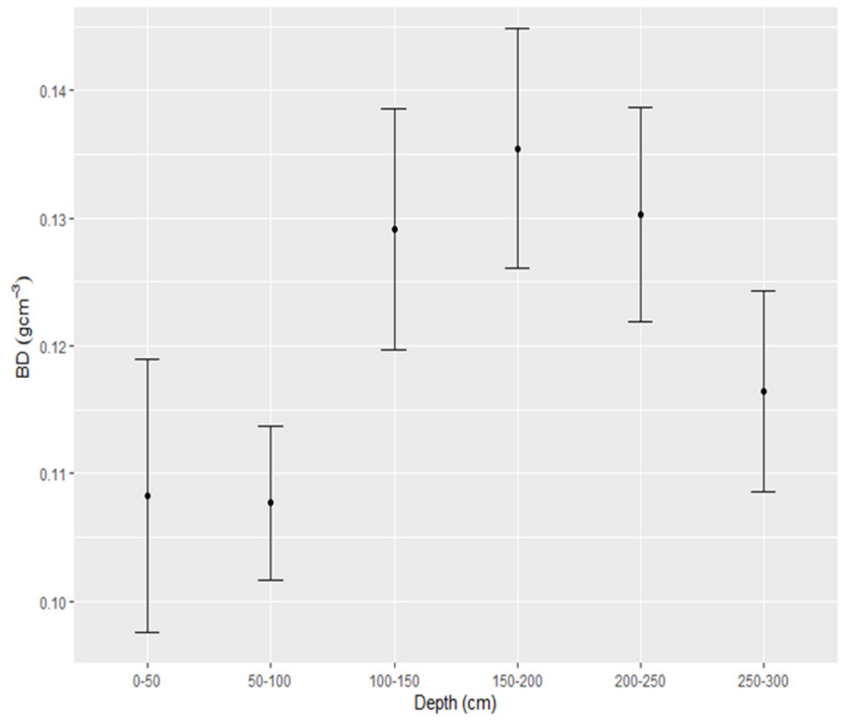

(a)

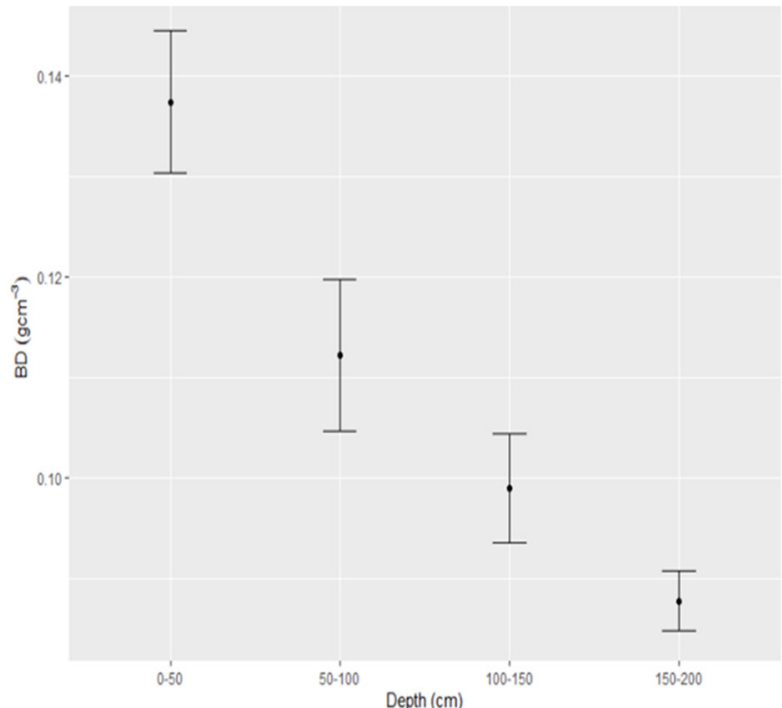

(b)

Figure 4. Mean plot \pm SE of bulk density (BD) in the undrained peat forest (a) and in the drained peatland (b).

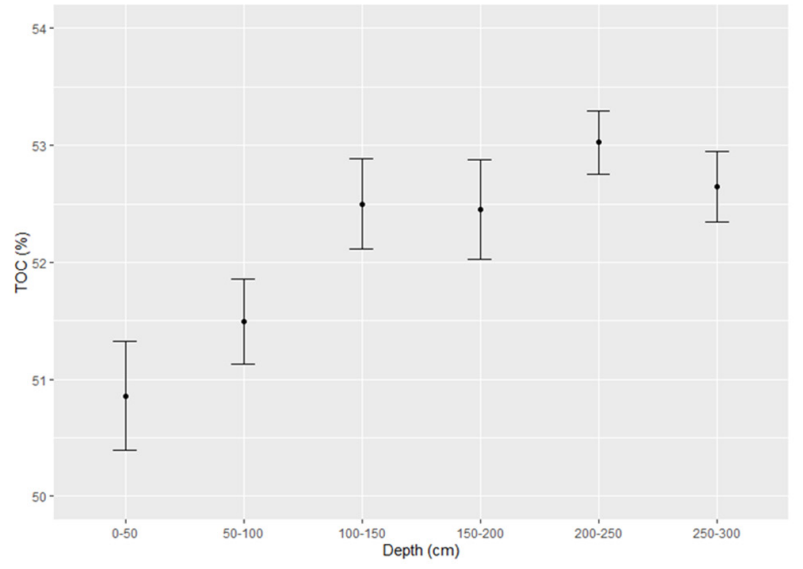

(a)

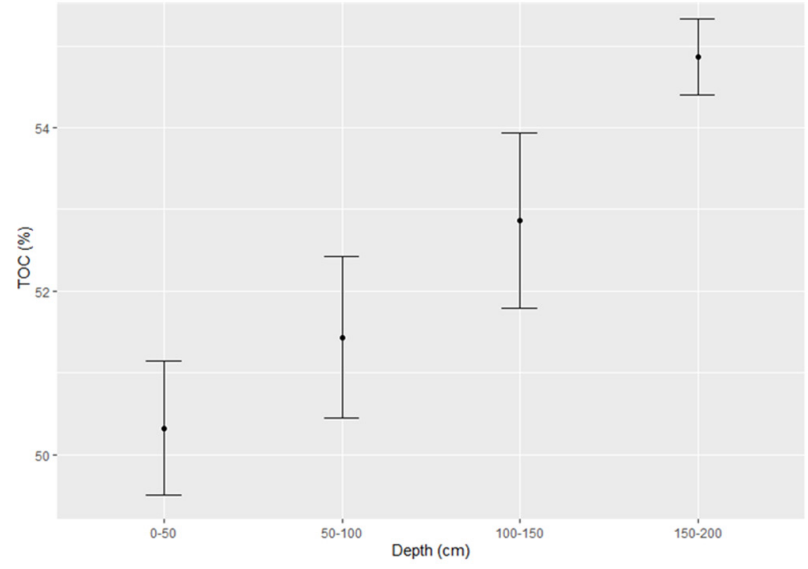

(b)

Figure 5. (a). Mean \pm SE of total organic carbon (TOC) in the undrained peat forest, and (b). in the drained peatland.

Figure $6 \mathrm{a}, \mathrm{b}$ show scatter plots between BD and TOC in the undrained and drained peats. Pearson correlations between $\mathrm{BD}$ and TOC in the undrained and drained peats are significant and become very strong in the drained peat. An increase in BD in the drained peat cause a significant decline in TOC, suggesting peat mineralization and carbon emission from deforested and drained peatland (See Figure 6b). Tonks et al. [48] reported a decline in TOC in relation to an increase in $\mathrm{BD}$, indicating that TOC in drained and disturbed peat is not stable $[89,90]$. The stability of carbon in tropical peat is secured if only the peatland is kept saturated at all times [91-93].

It is worth noting the importance of peat compaction for improving the bearing capacity of peat soil and enhancement of capillary water for maintaining soil moisture in dry spells. Adhi et al. [94] reported that the average increase in BD in the top 10-20 cm peat used for oil palm plantation range from 0.12 to $0.15 \mathrm{~g} \mathrm{~cm}^{-3}$, leading to the availability of capillary water throughout $30 \mathrm{~cm}$ peat surface. The average value of BD $(0-50 \mathrm{~cm})$ of peat planted with oil palm in Tanjung Puting, Central Kalimantan is $0.37 \mathrm{~g} \mathrm{~cm}^{-3}$ [95]. Wakhid et al. [56] noted the average BD of $0.23 \mathrm{~g} \mathrm{~cm}^{-3}$ in the top peat surface $(0-75 \mathrm{~cm})$ in the rubber plantation on peat. As shown in Figure $4 b$, high bulk density in the drained peat correlates with low carbon content or carbon loss. Tables S1 and S2 present BD and TOC in the undrained and drained peats. 


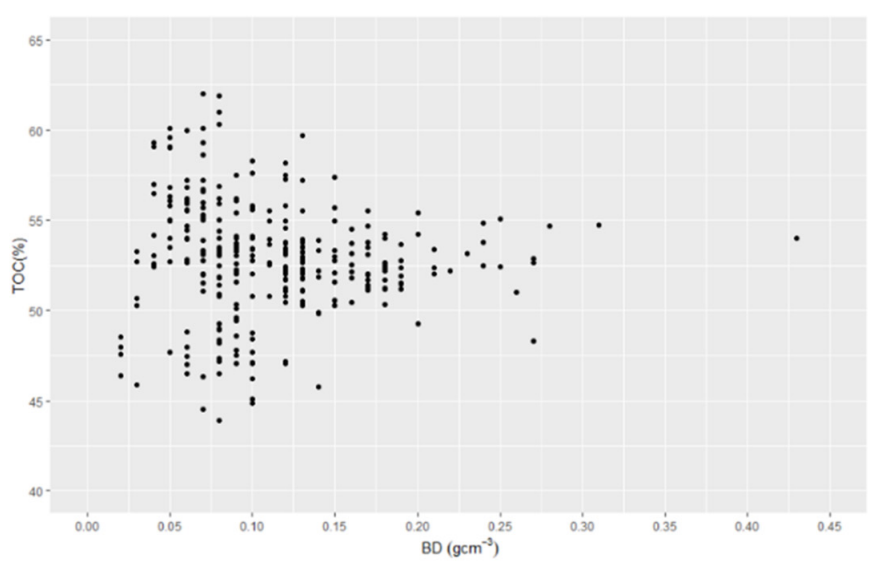

(a)

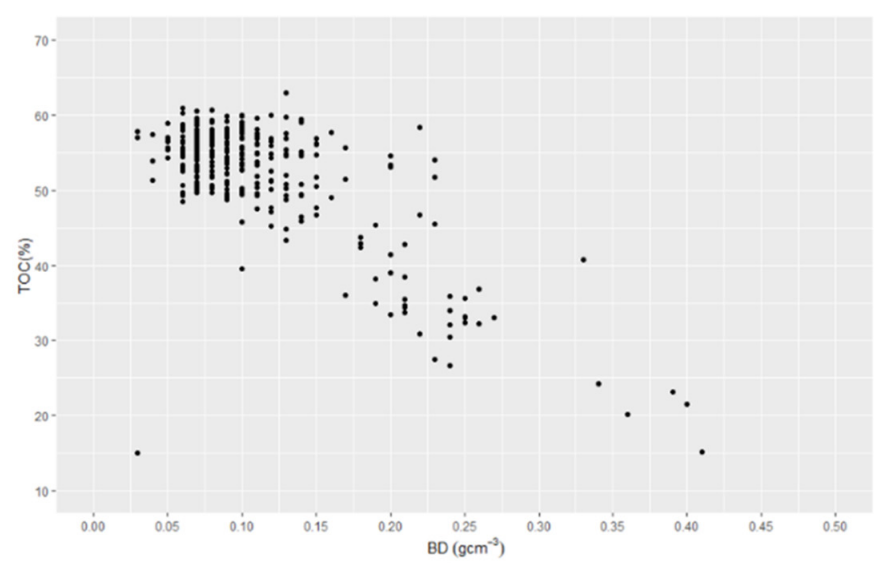

(b)

Figure 6. Scatter plots Bulk Density $\left(\mathrm{g} \mathrm{cm}^{-3}\right)$ and Total Organic Carbon (\%) showing (a) a low Pearson correlation (Pearson $\mathrm{R}=0.15, n=259$ ), in the undrained peat forest, and ( $\mathbf{b})$ a high negative Pearson correlation (Pearson $\mathrm{R}=-0.81, n=308)$ in the drained and deforested peat.

\section{Carbon Loss Estimate}

Bulk density (BD), TOC and peat subsidence (PS) can be used to estimate carbon loss in drained peat. Based on data shown in Figures 3 and 4, the mean BD in the top surface $(0-50 \mathrm{~cm})$ in the drained peat is $0.14 \mathrm{~g} \mathrm{~cm}^{-3}$, and the mean BD value in the top surface $(0-50 \mathrm{~cm})$ in the peat forest is $0.11 \mathrm{~g} \mathrm{~cm}^{-3}$. Mean TOC values in the top surface $(0-50 \mathrm{~cm})$ in both the drained and undrained peat forest is about $50 \%$. Based on these values, the formula to estimate carbon loss due to an increase in bulk density caused by drainage and land use disturbance can be calculated using the following equation:

$$
\mathrm{CL}_{50}=\mathrm{CD} \times \mathrm{PVL} \times 0.6 \times 3.66
$$

where:

$\mathrm{CL}_{50}=$ carbon loss $\left(\mathrm{t} \mathrm{CO}_{2 \text {-eq }} \mathrm{ha}^{-1} \mathrm{yr}^{-1}\right)$ from the top peat surface $(0-50 \mathrm{~cm})$

$\mathrm{CD}=$ carbon density $\left(\mathrm{t} \mathrm{C} \mathrm{m}^{-3}\right)=\mathrm{BD}\left(\mathrm{t} \mathrm{m}^{-3}\right) \times \mathrm{TOC}(\%)=0.14 \times 50 \%=0.07 \mathrm{t} \mathrm{C} \mathrm{m}^{-3}$

$\mathrm{PVL}=$ peat volume loss $\left(\mathrm{m}^{3} \mathrm{ha}^{-1} \mathrm{yr}^{-1}\right)=$ subsidence rate $\left(\mathrm{m} \mathrm{yr}^{-1}\right) \times 10,000 \mathrm{~m}^{2}$

0.6 is a factor of oxidized subsidence (adopted from [8])

3.66 is a conversion factor elemental $\mathrm{C}$ to $\mathrm{CO}_{2 \text {-eq }}$

Using the equation above and the previously mentioned BD and TOC values, every $1 \mathrm{~cm}$ per year subsidence in the drained peat emits 13 to $16 \mathrm{t} \mathrm{CO}_{2 \mathrm{e}} \mathrm{ha}^{-1} \mathrm{yr}^{-1}$, with an average of $15 \mathrm{t} \mathrm{CO}_{2 \mathrm{e}} \mathrm{ha}^{-1} \mathrm{yr}^{-1}$. Using a conservative estimate of subsidence rate (see Table 2), ranging 2 to $6 \mathrm{~cm}$ per year, carbon loss from drained peatlands is estimated at 30 to $90 \mathrm{t} \mathrm{CO}_{2 \mathrm{e}} \mathrm{ha}^{-1} \mathrm{yr}^{-1}$. A record of carbon emission from previous studies is compiled in supplementary data (see Table S2). The default value of IPCC carbon emission from oil palm on peat is $40 \mathrm{t} \mathrm{CO}_{2 \mathrm{e}} \mathrm{ha}^{-1} \mathrm{yr}^{-1}$ [70]. Table $\mathrm{S} 3$ summarizes heterotrophic $\mathrm{CO}_{2}$ emissions from different land-use systems of peatland in Indonesia.

Table 2 presents selected data of subsidence rates in tropical peat of Sumatra and Kalimantan. The range of subsidence rate is conservatively between 2 to $6 \mathrm{~cm}$ per year. This data further supports the previous studies that drainage intensity persistently causes peat subsidence [96]. 
Table 2. Subsidence rates under different land use systems in SE Asian drained peatland.

\begin{tabular}{|c|c|c|c|c|c|c|c|c|}
\hline \multirow{2}{*}{ No } & \multirow{2}{*}{ Subsidence Class } & \multirow{2}{*}{$\begin{array}{l}\text { Subsidence Rate } \\
\left(\mathrm{cm} \mathrm{yr}^{-1}\right)\end{array}$} & \multirow{2}{*}{$\begin{array}{c}\text { Period of } \\
\text { Drainage (yrs) }\end{array}$} & \multicolumn{2}{|c|}{$\begin{array}{c}\text { C Emission } \\
\left(\mathrm{Mg} \mathrm{CO}_{2 \mathrm{e}} \mathrm{ha}^{-1} \mathrm{yr}^{-1}\right)\end{array}$} & \multirow{2}{*}{ Land Use } & \multirow{2}{*}{ Location } & \multirow{2}{*}{ Reference } \\
\hline & & & & $\begin{array}{l}\text { Published C } \\
\text { Emission }\end{array}$ & This Study & & & \\
\hline 1 & $\begin{array}{c}\text { Low } \\
\left(0.3-1.99 \mathrm{~cm} \mathrm{yr}^{-1}\right)\end{array}$ & 1.10 & 15.00 & 4.34 & 16.91 & $\begin{array}{l}\text { Community oil palm } \\
\text { plantation }\end{array}$ & Aceh Province & [97] \\
\hline 2 & $\begin{array}{c}\text { Low } \\
\left(0.3-1.99 \mathrm{~cm} \mathrm{yr}^{-1}\right)\end{array}$ & 1.20 & 15.00 & 2.39 & 18.45 & $\begin{array}{c}\text { Community rubber } \\
\text { plantation }\end{array}$ & Aceh Province & [97] \\
\hline 3 & $\begin{array}{c}\text { Low } \\
\left(0.3-1.99 \mathrm{~cm} \mathrm{yr}^{-1}\right)\end{array}$ & 2.00 & 20.00 & 26.50 & 30.74 & Agriculture & Western Johor, Malaysia & [8] \\
\hline 4 & $\begin{array}{c}\text { Low } \\
\left(0.3-1.99 \mathrm{~cm} \mathrm{yr}^{-1}\right)\end{array}$ & 0.40 & 36.00 & - & 6.15 & Agriculture & $\begin{array}{c}\text { Kalampangan, Central } \\
\text { Kalimantan }\end{array}$ & [98] \\
\hline 5 & $\begin{array}{c}\text { Low } \\
\left(0.3-1.99 \mathrm{~cm} \mathrm{yr}^{-1}\right)\end{array}$ & 0.36 & 12.00 & - & 5.53 & $\begin{array}{l}\text { Community oil palm } \\
\text { plantation }\end{array}$ & $\begin{array}{c}\text { Hampangan, Central } \\
\text { Kalimantan }\end{array}$ & [98] \\
\hline 6 & $\begin{array}{c}\text { Moderate } \\
\left(2.0-3.99 \mathrm{~cm} \mathrm{yr}^{-1}\right)\end{array}$ & 3.90 & 5.00 & 62.81 & 59.95 & Oil palm & Indonesia & [10] \\
\hline 7 & $\begin{array}{c}\text { Moderate } \\
\left(2.0-3.99 \mathrm{~cm} \mathrm{yr}^{-1}\right)\end{array}$ & 3.70 & 19.00 & 59.58 & 56.88 & Oil palm & Indonesia & [10] \\
\hline 8 & $\begin{array}{c}\text { Moderate } \\
\left(2.0-3.99 \mathrm{~cm} \mathrm{yr}^{-1}\right)\end{array}$ & 3.90 & 12.00 & 64.42 & 59.95 & Oil palm & $\begin{array}{c}\text { Kampar Peninsula, Riau, } \\
\text { Sumatra }\end{array}$ & [99] \\
\hline 9 & $\begin{array}{c}\text { Moderate } \\
\left(2.0-3.99 \mathrm{~cm} \mathrm{yr}^{-1}\right)\end{array}$ & 3.70 & 12.00 & 58.19 & 56.88 & Oil palm & $\begin{array}{c}\text { Kampar Peninsula, Riau, } \\
\text { Sumatra }\end{array}$ & [99] \\
\hline 10 & $\begin{array}{c}\text { Moderate } \\
\left(2.0-3.99 \mathrm{~cm} \mathrm{yr}^{-1}\right)\end{array}$ & 2.80 & 15.00 & 5.82 & 43.04 & $\begin{array}{l}\text { Community rubber } \\
\text { plantation }\end{array}$ & Aceh Province & [97] \\
\hline 11 & $\begin{array}{c}\text { Moderate } \\
\left(2.0-3.99 \mathrm{~cm} \mathrm{yr}^{-1}\right)\end{array}$ & 2.60 & 30.00 & 75.00 & 39.97 & $\begin{array}{l}\text { Community rubber } \\
\text { plantation }\end{array}$ & $\begin{array}{l}\text { Tanjung Jabung Barat, } \\
\text { Jambi Province }\end{array}$ & [72] \\
\hline 12 & $\begin{array}{c}\text { Moderate } \\
\left(2.0-3.99 \mathrm{~cm} \mathrm{yr}^{-1}\right)\end{array}$ & 2.40 & 20.00 & 71.00 & 36.89 & Mixed agriculture & $\begin{array}{c}\text { Tanjung Jabung Barat, } \\
\text { Jambi Province }\end{array}$ & [72] \\
\hline 13 & $\begin{array}{c}\text { Moderate } \\
\left(2.0-3.99 \mathrm{~cm} \mathrm{yr}^{-1}\right)\end{array}$ & 2.80 & 40.00 & 85.00 & 43.04 & Mixed agriculture & $\begin{array}{c}\text { Tanjung Jabung Barat, } \\
\text { Jambi Province }\end{array}$ & [72] \\
\hline 14 & $\begin{array}{c}\text { Moderate } \\
\left(2.0-3.99 \mathrm{~cm} \mathrm{yr}^{-1}\right)\end{array}$ & 2.20 & 10.00 & - & 33.82 & All agricultural drained peat & Southeast Asia & [63] \\
\hline 15 & $\begin{array}{c}\text { Moderate } \\
\left(2.0-3.99 \mathrm{~cm} \mathrm{yr}^{-1}\right)\end{array}$ & 3.21 & 6.00 & - & 49.34 & Agriculture & $\begin{array}{l}\text { Misik, Central } \\
\text { Kalimantan }\end{array}$ & [98] \\
\hline
\end{tabular}


Table 2. Cont.

\begin{tabular}{|c|c|c|c|c|c|c|c|c|}
\hline \multirow{2}{*}{ No } & \multirow{2}{*}{ Subsidence Class } & \multirow{2}{*}{$\begin{array}{l}\text { Subsidence Rate } \\
\left(\mathrm{cm} \mathrm{yr}^{-1}\right)\end{array}$} & \multirow{2}{*}{$\begin{array}{c}\text { Period of } \\
\text { Drainage (yrs) }\end{array}$} & \multicolumn{2}{|c|}{$\begin{array}{c}\text { C Emission } \\
\left(\mathrm{Mg} \mathrm{CO}_{2 \mathrm{e}} \mathrm{ha}^{-1} \mathrm{yr}^{-1}\right)\end{array}$} & \multirow{2}{*}{ Land Use } & \multirow{2}{*}{ Location } & \multirow{2}{*}{ Reference } \\
\hline & & & & $\begin{array}{c}\text { Published C } \\
\text { Emission }\end{array}$ & This Study & & & \\
\hline 16 & $\begin{array}{c}\text { High } \\
\left(4.0-5.99 \mathrm{~cm} \mathrm{yr}^{-1}\right)\end{array}$ & 4.30 & 24.00 & 80.00 & 66.10 & Acacia plantation & Riau, Sumatra & {$[64]$} \\
\hline 17 & $\begin{array}{c}\text { High } \\
\left(4.0-5.99 \mathrm{~cm} \mathrm{yr}^{-1}\right)\end{array}$ & 5.00 & 6.00 & 74.48 & 76.86 & Acacia plantation & Indonesia & [10] \\
\hline 18 & $\begin{array}{c}\text { High } \\
\left(4.0-5.99 \mathrm{~cm} \mathrm{yr}^{-1}\right)\end{array}$ & 5.00 & 14.00 & 74.30 & 76.86 & Acacia plantation & $\begin{array}{c}\text { Kampar Peninsula, Riau, } \\
\text { Sumatra }\end{array}$ & [99] \\
\hline 19 & $\begin{array}{c}\text { High } \\
\left(4.0-5.99 \mathrm{~cm} \mathrm{yr}^{-1}\right)\end{array}$ & 4.80 & 15.00 & 25.23 & 73.79 & $\begin{array}{l}\text { Community oil palm } \\
\text { plantation }\end{array}$ & Aceh Province & [97] \\
\hline 20 & $\begin{array}{c}\text { High } \\
\left(4.0-5.99 \mathrm{~cm} \mathrm{yr}^{-1}\right)\end{array}$ & 5.90 & 20.00 & 53.20 & 90.69 & $\begin{array}{c}\text { Community rubber } \\
\text { plantation }\end{array}$ & Central Kalimantan & {$[56]$} \\
\hline 21 & $\begin{array}{c}\text { High } \\
\left(4.0-5.99 \mathrm{~cm} \mathrm{yr}^{-1}\right)\end{array}$ & 5.00 & 25.00 & 76.00 & 76.86 & Acacia and oil palm & Riau and Jambi & [99] \\
\hline 22 & $\begin{array}{c}\text { High } \\
\left(4.0-5.99 \mathrm{~cm} \mathrm{yr}^{-1}\right)\end{array}$ & 5.27 & 6.00 & - & 81.01 & $\begin{array}{l}\text { Community oil palm } \\
\text { plantation }\end{array}$ & $\begin{array}{l}\text { Misik, Central } \\
\text { Kalimantan }\end{array}$ & [98] \\
\hline 23 & $\begin{array}{l}\text { Very High } \\
\left(>6.0 \mathrm{~cm} \mathrm{yr}^{-1}\right)\end{array}$ & 8.20 & 10.00 & 38.88 & 126.05 & $\begin{array}{l}\text { Community oil palm } \\
\text { plantation }\end{array}$ & Aceh Province & [97] \\
\hline 24 & $\begin{array}{c}\text { Very High } \\
\left(>6.0 \mathrm{~cm} \mathrm{yr}^{-1}\right)\end{array}$ & 9.20 & 10.00 & 40.64 & 141.42 & $\begin{array}{l}\text { Community oil palm } \\
\text { plantation }\end{array}$ & Aceh Province & [97] \\
\hline \multirow[t]{4}{*}{25} & $\begin{array}{c}\text { Very High } \\
\left(>6.0 \mathrm{~cm} \mathrm{yr}^{-1}\right)\end{array}$ & 8.20 & 1.00 & 48.09 & 126.05 & $\begin{array}{l}\text { Community oil palm } \\
\text { plantation }\end{array}$ & Aceh Province & [97] \\
\hline & Min & 0.36 & 1.00 & 2.39 & 5.53 & & & \\
\hline & Max & 9.20 & 40.00 & 85.00 & 141.42 & & & \\
\hline & Mean & 3.89 & 15.92 & 51.29 & 59.73 & & & \\
\hline
\end{tabular}


Drainage and land use disturbance on peat cause peat subsidence everywhere in this world $[59,63,68,100-103]$. In the first year of drainage, the rate of peat subsidence is very high. Then, the peat subsidence rate is stabilized in the long term, for example, five years post-drainage construction [8]. The rate of subsidence in the drained peat is continuous; hence, carbon emission persistently occurs. Rewetting the drained peat and the subsequent water management would reduce the subsidence rate at about $20-30 \%[1,64]$. This suggests peat oxidation in the drained peat causes a large amount of carbon emission. The availability of oxygen in the top peat layer above the groundwater table leads to significant microbial activities that decompose organic compounds in peats [54,104,105]. Peat subsidence in converted and drained peats is irreversible and endless.

\section{Assessment of Peat Subsidence and C Emission}

The rate of peat subsidence is varied (See Table 2). On average, post 16 years of drainage, the average rate of subsidence is $3.9 \mathrm{~cm} \mathrm{yr}^{-1}$. The amount of $C$ emission reported in literature ranged from 2.39 to 85.00 , with an average of $51.29 \mathrm{Mg} \mathrm{CO}_{2} \mathrm{e} \mathrm{ha}^{-1} \mathrm{yr}^{-1}$. In general, the reported $\mathrm{C}$ emission is relatively close to the 2013 IPCC default values of the $\mathrm{CO}_{2} \mathrm{e}$ emission factor in drained tropical peats, ranging from 5.5 to $73 \mathrm{Mg} \mathrm{CO}_{2} \mathrm{e} \mathrm{ha}^{-1} \mathrm{yr}^{-1}$. Moreover, using Equation (1) above, the estimated $\mathrm{C}$ emission in this study ranged from 5.53 to $141.42 \mathrm{Mg} \mathrm{CO}_{2} \mathrm{e} \mathrm{ha}^{-1} \mathrm{yr}^{-1}$, with an average of $59.73 \mathrm{Mg} \mathrm{CO}_{2} \mathrm{e} \mathrm{ha}^{-1} \mathrm{yr}^{-1}$. Figure 7 presents scatter plots between published $\mathrm{C}$ emission based on subsidence rates and the calculated C emission based on Equation (1). The calculated C emission in this review is linear with a subsidence rate. The estimated $C$ emission caused by $1 \mathrm{~cm}$ peat subsidence is about $15.4 \mathrm{Mg} \mathrm{CO}_{2} \mathrm{e} \mathrm{ha}^{-1} \mathrm{yr}^{-1}$. On average, the estimated $\mathrm{C}$ emission from drained tropical peat in Indonesia is $60 \mathrm{Mg} \mathrm{CO}_{2} \mathrm{e} \mathrm{ha}^{-1} \mathrm{yr}^{-1}$.

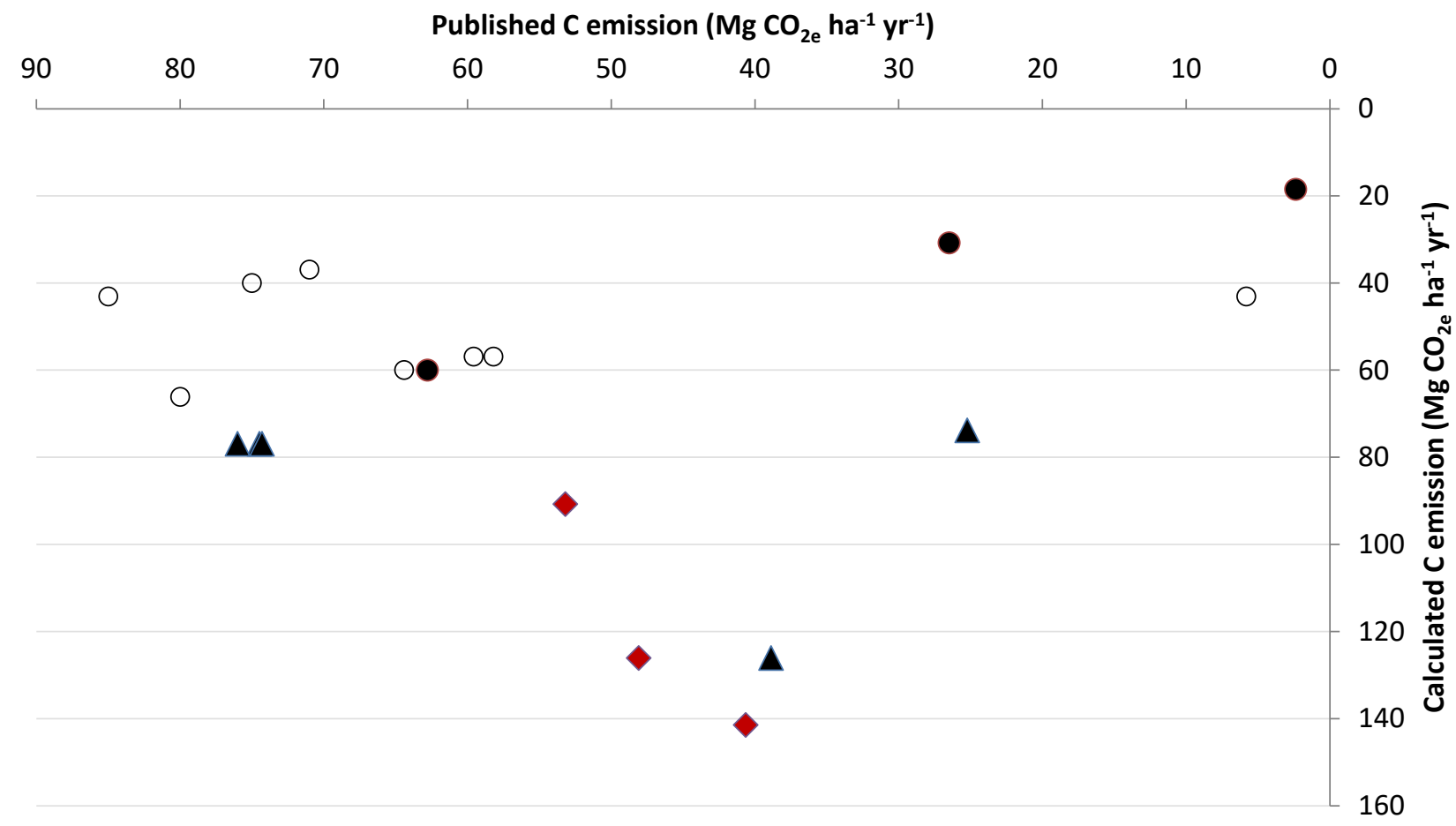

- Low $(0.3-1.99 \mathrm{~cm} / \mathrm{yr}) \quad$ O Moderate $(2.0-3.99 \mathrm{~cm} / \mathrm{yr}) \quad \Delta$ High $(4.0-5.99 \mathrm{~cm} / \mathrm{yr}) \quad$ Very high $(>6.0 \mathrm{~cm} / \mathrm{yr})$

Figure 7. A scatter plot between subsidence rate and published $\mathrm{C}$ emission data and calculated $\mathrm{C}$ emission based on subsidence rates. 


\section{Policy Implication}

Despite complex issues and views on peat degradation, ecological degradation of tropical peat forests consists of hydrological change and alteration of peat soil properties. Analysis of ex-ante and ex-post water balance is required to understand the natures of hydrological changes, which then requires a long record of selected climate data, i.e., precipitation, air temperatures, wind, and humidity, which is, unfortunately, commonly unavailable. Field measurements of hydrological properties such as evaporation, hydraulic conductivity, water table height, and water permeability are recommended. Next, selected peat properties, such as $\mathrm{BD}, \mathrm{TOC}$, and $\mathrm{TN}$, are important parameters to estimate carbon stock. To manage land productivity, several soil fertility variables, such as $\mathrm{pH}$ and nutrients, should be frequently monitored. To sum, it may not be appropriate to assess peatland degradation based only on the $40 \mathrm{~cm}$ groundwater table, the exposure of sulfidic materials into acid sulfate soil, and the exposure of quartz sand alone. These criteria are stipulated in the current Indonesian government regulation (See Government Regulation No. 16/2017 on Technical Guideline for Peatland Restoration). Figure 8 summarizes factors that govern tropical peat forest degradation in Indonesia.

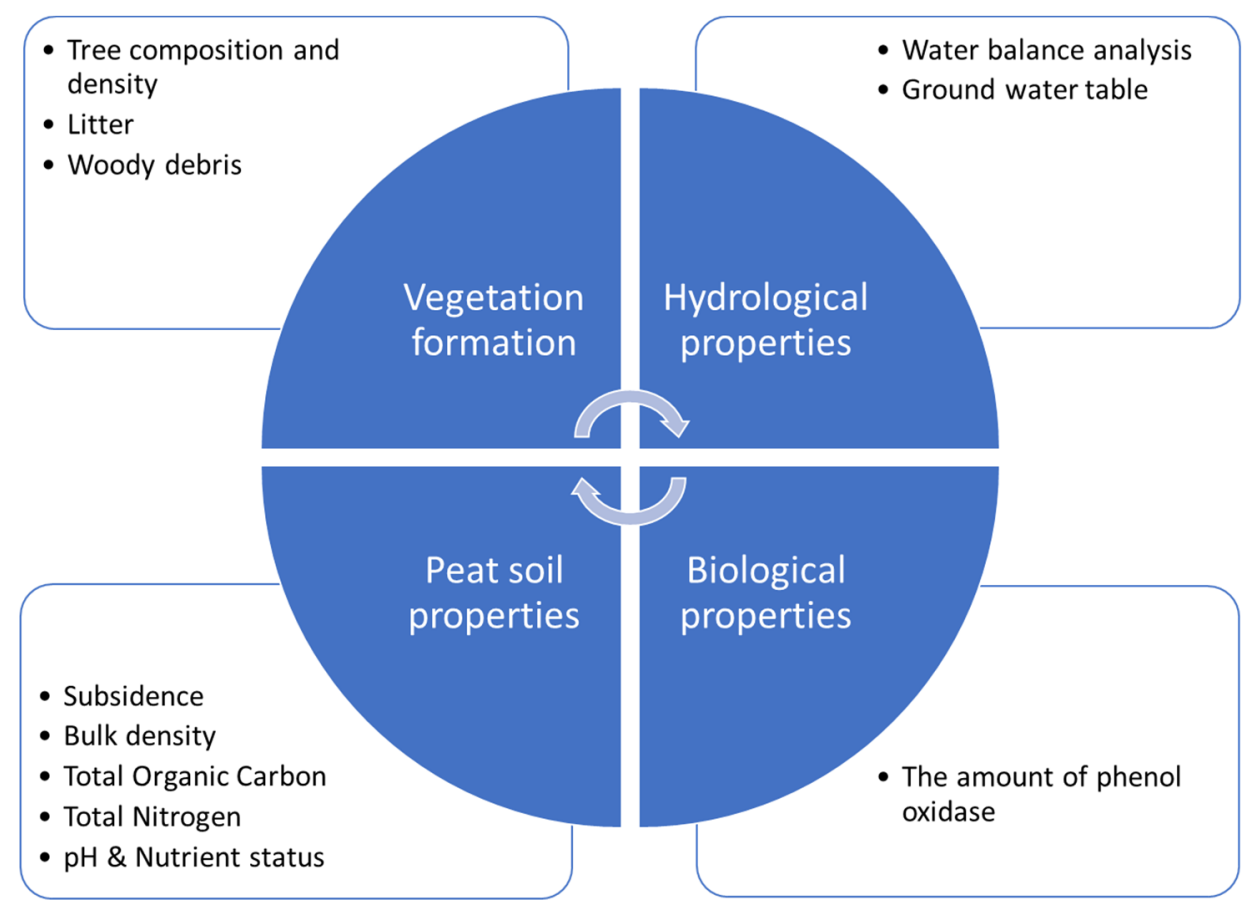

Figure 8. Factors that control tropical peat forest degradation in Indonesia.

The current policy on the tropical peat ecosystem in Indonesia focuses on the monitoring of groundwater tables. It is mandatory for all oil palm and timber concession in Indonesia to control the height of the groundwater table at $40 \mathrm{~cm}$ all year. In reality, the height of the groundwater table significantly drops, even beyond $100 \mathrm{~cm}$, during prolonged dry seasons associated with extreme years of El Niño. The importance of a high-water table for controlling peat fire is not arguable. Furthermore, high groundwater table reduces the subsidence rates [98]. A waterlogged environment also might reduce carbon emission, despite an increase in $\mathrm{CH}_{4}$ emission. In addition to good water management for keeping a high groundwater table, the subsidence rate measurement is substantially practical to estimate the amounts of carbon emission because the rate of subsidence directly indicates the amount of carbon emission. The contribution of chemical decomposition to subsidence is conservatively about $60 \%$ [8]. A high concentration of aromatic organic compounds slows the oxidative rate of tropical peat decomposition [21,106]. 


\section{Conclusion and Recommendation}

This paper reports that drainage causes an increase in bulk density and TOC decline in the drained upper peat layer, which creates a favorable condition for peat decomposition. Both bulk density and TOC in the undrained peat forest do not alter either in the upper aerobic or inundated bottom peat layers. The use of a groundwater table to estimate carbon loss in drained peat is commonly practiced. Nevertheless, the groundwater table does not always positively correlate with carbon emission measured with the closed chamber. This paper proposes subsidence as a robust and straightforward calculation of carbon emission from drained peats used for all agricultures. Therefore, the Indonesian government and other tropical countries that have peats should consider subsidence as an alternative approach to the groundwater table to estimate carbon loss in drained peat.

Supplementary Materials: The following are available online at https:/ /www.mdpi.com/article/10 $.3390 / \mathrm{f12060732/s1,} \mathrm{Table} \mathrm{S1:} \mathrm{Bulk} \mathrm{density} \mathrm{(BD)} \mathrm{and} \mathrm{total} \mathrm{organic} \mathrm{carbon} \mathrm{(TOC)} \mathrm{in} \mathrm{the} \mathrm{undrained} \mathrm{peat}$ forests; Table S2: Bulk density (BD) and total organic carbon (TOC) in the drained peat forests.Table S3: Total and heterotrophic $\mathrm{CO}_{2}$ emissions from different land use systems of peatland in Indonesia.

Author Contributions: G.Z.A., E.G. contribute for writing and original draft preparation, editing and review. N.N. contributes for conceptualization, editing, review and funding acquisition. All authors have read and agreed to the published version of the manuscript.

Funding: This research was funded by NORAD, grant number GLO-4251 QZA-16/0172. The APC was funded by NORAD.

Institutional Review Board Statement: No applicable.

Informed Consent Statement: Not applicable.

Data Availability Statement: All data are available in the article and supplementary materials.

Acknowledgments: Feedbacks from both Fahmuddin Agus and DIvan Titaley are gratefully acknowledged.

Conflicts of Interest: The authors declare no conflict of interest. The funders had no role in the design of the study; in the collection, analyses, or interpretation of data; in the writing of the manuscript, or in the decision to publish the results.

\section{References}

1. Hooijer, A.; Page, S.; Navratil, P.; Vernimmen, R.; van der Vat, M.; Tansey, K.; Konecny, K.; Siegert, F.; Ballhorn, U.; Mawdsley, N. Carbon Emissions from Drained and Degraded Peatland in Indonesia and Emission Factors for Measurement, Reporting and Verification $(M R V)$ of Peatland Greenhouse Gas Emissions-A Summary of KFCP Research Results for Practioners; IAFCP: Jakarta, Indonesia, 2014.

2. Jauhiainen, J.; Hooijer, A.; Page, S.E. Carbon dioxide emissions from an Acacia plantation on peatland in Sumatra, Indonesia. Biogeosciences 2012, 9, 617-630. [CrossRef]

3. Miettinen, J.; Wang, J.; Hooijer, A.; Liew, S. Peatland Conversion and Degradation Processes in Insular Southeast Asia: A Case Study in Jambi, Indonesia. Land Degrad. Dev. 2013, 24, 334-341. [CrossRef]

4. Hooijer, A.; Page, S.; Jauhiainen, J.; Lee, W.A.; Lu, X.X.; Idris, A.B.; Anshari, G. Subsidence and carbon loss in drained tropical peatlands. Biogeosciences 2012, 9, 1053-1071. [CrossRef]

5. Mishra, S.R.; Lee, W.A.; Hooijer, A.; Reuben, S.; Sudiana, I.M.; Idris, A.; Swarup, S. Microbial and metabolic profiling reveal strong influence of water table and land-use patterns on classification of degraded tropical peatlands. Biogeosciences 2014, 11, 1727-1741. [CrossRef]

6. Agus, F.; Henson, I.E.; Sahardjo, B.H.; Harris, N.; van Noordwijk, M.; Killeen, T. Review of Emission Factors for Assessment of $\mathrm{CO}_{2}$ Emission from Land Use Change to Oil Palm in Southeast Asia, Kualalumpur. 2013. Available online: http:/ /www.rspo. org/file/GHGWG2/3_review_of_emission_factors_Agus_et_al.pdf (accessed on 16 April 2019).

7. Regina, K.; Sheehy, J.; Myllys, M. Mitigating greenhouse gas fluxes from cultivated organic soils with raised water table. Mitig. Adapt. Strat. Glob. Chang. 2014, 20, 1529-1544. [CrossRef]

8. Wösten, J.; Ismail, A.; van Wijk, A. Peat subsidence and its practical implications: A case study in Malaysia. Geoderma 1997, 78, 25-36. [CrossRef]

9. Wösten, J.H.M.; Berg, J.V.D.; Van Eijk, P.; Gevers, G.J.M.; Giesen, W.B.J.T.; Hooijer, A.; Idris, A.; Leenman, P.H.; Rais, D.S.; Siderius, C.; et al. Interrelationships between Hydrology and Ecology in Fire Degraded Tropical Peat Swamp Forests. Int. J. Water Resour. Dev. 2006, 22, 157-174. [CrossRef] 
10. Couwenberg, J.; Hooijer, A. Towards Robust Subsidence-Based Soil Carbon Emission Factors for Peat Soils in SouthEast ASIA, with Special Reference to Oil Palm Plantations. Mires Peat 2013, 12, 1-13. Available online: http://pixelrauschen.de/wbmp/ media/map12/map_12_01.pdf (accessed on 7 April 2015).

11. Gusmayanti, E.; Anshari, G.; Pramulya, M.; Ruliyansyah, A. CO2 fluxes from drained tropical peatland used for oil palm plantation in relation to peat characteristics and crop age after planting. Biodiversitas J. Biol. Divers. 2019, 20, 1650-1657. [CrossRef]

12. Nurzakiah, S.; Wakhid, N.; Hairani, A. Carbon dioxide emission and peat hydrophobicity in tidal peatlands. SAINS TANAH-J. Soil Sci. Agroclimatol. 2020, 17, 71-77. [CrossRef]

13. Kimura, S.D.; Melling, L.; Goh, K.J. Influence of soil aggregate size on greenhouse gas emission and uptake rate from tropical peat soil in forest and different oil palm development years. Geoderma 2012, 185-186, 1-5. [CrossRef]

14. Girkin, N.; Turner, B.L.; Ostle, N.; Craigon, J.; Sjögersten, S. Root exudate analogues accelerate CO2 and CH4 production in tropical peat. Soil Biol. Biochem. 2018, 117, 48-55. [CrossRef]

15. Bader, C.; Müller, M.; Schulin, R.; Leifeld, J. Peat decomposability in managed organic soils in relation to land use, organic matter composition and temperature. Biogeosciences 2018, 15, 703-719. [CrossRef]

16. Bourgeau-Chavez, L.L.; Endres, S.L.; Graham, J.A.; Hribljan, J.A.; Chimner, R.A.; Lillieskov, E.A.; Battaglia, M.J. Mapping peatlands in boreal and tropical ecoregions. In Comprehensive Remote Sensing, 1st ed.; Liang, S., Ed.; Elsevier: Amsterdam, The Netherlands, 2017; Volume 6, pp. 24-44.

17. $\mathrm{Xu}, \mathrm{J} . ;$ Morris, P.J.; Liu, J.; Holden, J. PEATMAP: Refining estimates of global peatland distribution based on a meta-analysis. Catena 2018, 160, 134-140. [CrossRef]

18. FAO. World Reference Base for Soil Resources 2014. International Soil Classification System for Naming Soils and Creating Legends for Soil Maps; FAO: Rome, Italy, 2014.

19. Householder, J.; Wittmann, F.; Tobler, M.; Janovec, J. Montane bias in lowland Amazonian peatlands: Plant assembly on heterogeneous landscapes and potential significance to palynological inference. Palaeogeogr. Palaeoclim. Palaeoecol. 2015, 423, 138-148. [CrossRef]

20. Hope, G.S. Peat in the Mountains of New Guinea. Mires Peat 2015, 15, 1-21.

21. Andriesse, J.P. Nature and Management of Tropical Peat Soils; FAO Soil Bulletin 59: Rome, Italy, 1988.

22. Page, S.; Rieley, J.O.; Banks, C.J. Global and regional importance of the tropical peatland carbon pool. Glob. Chang. Biol. 2011, 17, 798-818. [CrossRef]

23. Rieley, J.; Page, S. Tropical Peatland of the World, in Tropical Peatland Ecosystems; Osaki, M., Tsuji, N., Eds.; Springer: Tokyo, Japan, 2016.

24. Dargie, G.C.; Lawson, I.T.; Rayden, T.J.; Miles, L.; Mitchard, E.T.A.; Page, S.E.; Bocko, Y.E.; Ifo, S.A.; Lewis, S.L. Congo Basin peatlands: Threats and conservation priorities. Mitig. Adapt. Strat. Glob. Chang. 2019, 24, 669-686. [CrossRef]

25. Page, S.E.; Banks, C.J.; Rieley, J.O. Tropical Peatlands: Distribution, Extent and Carbon Storage-Uncertainties and Knowledge Gaps. Peatl. Int. 2007, 2, 26-27.

26. Gumbricht, T.; Roman-Cuesta, R.M.; Verchot, L.; Herold, M.; Wittmann, F.; Householder, E.; Herold, N.; Murdiyarso, D. An expert system model for mapping tropical wetlands and peatlands reveals South America as the largest contributor. Glob. Chang. Biol. 2017, 23, 3581-3599. [CrossRef]

27. Lampela, M.; Jauhiainen, J.; Kämäri, I.; Koskinen, M.; Tanhuanpää, T.; Valkeapää, A.; Vasander, H. Ground surface microtopography and vegetation patterns in a tropical peat swamp forest. Catena 2016, 139, 127-136. [CrossRef]

28. Lampela, M.; Jauhiainen, J.; Vasander, H. Surface peat structure and chemistry in a tropical peat swamp forest. Plant Soil 2014, 382, 329-347. [CrossRef]

29. Zweig, C.L.; Newman, S.; Saunders, C.J.; Sklar, F.H.; Kitchens, W.M. Deviations on a theme: Peat patterning in sub-tropical landscapes. Ecol. Model. 2018, 371, 25-36. [CrossRef]

30. Anderson, J.A.R. The Flora of the Peat Swamp Forest of Sarawak and Brunei, including a Catalogue of all Recorded Species of Flowering Plants, Ferns, and Fern Allies; Singapore Gardens Bulletin: Singapore, 1963; Volume 20, pp. 131-228.

31. Anderson, J.; Muller, J. Palynological study of a holocene peat and a miocene coal deposit from NW Borneo. Rev. Palaeobot. Palynol. 1975, 19, 291-351. [CrossRef]

32. Page, S.E.; Rieley, J.O.; Shotyk, Ø.W.; Weiss, D. Interdependence of peat and vegetation in a tropical peat swamp forest. Philos. Trans. R. Soc. B Biol. Sci. 1999, 354, 1885-1897. [CrossRef]

33. Kuniyasu, M.M.; Tetsuya, S.B. Environments and People of Sumatran Peat Swamp Forests I: Distribution and Typology of Vegetation. Jpn. J. Southeast Asian Stud. 2002, 40, 74-86.

34. Gallego-Sala, A.V.; Charman, D.J.; Brewer, S.; Page, S.E.; Prentice, I.C.; Friedlingstein, P.; Moreton, S.; Amesbury, M.J.; Beilman, D.W.; Björck, S.; et al. Latitudinal limits to the predicted increase of the peatland carbon sink with warming. Nat. Clim. Chang. 2018, 8, 907-913. [CrossRef]

35. Brady, M.A. Organic Matter Dynamis of Coastal Peat Deposits in Sumatra; British Columbia University: Vancouver, BC, Canada, 1997.

36. Houghton, R.A.; House, J.I.; Pongratz, J.; Van Der Werf, G.R.; DeFries, R.S.; Hansen, M.C.; Le Quéré, C.; Ramankutty, N. Carbon emissions from land use and land-cover change. Biogeosciences 2012, 9, 5125-5142. [CrossRef]

37. Loisel, J.; Gallego-Sala, A.V.; Amesbury, M.J.; Magnan, G.; Anshari, G.; Beilman, D.W.; Benavides, J.C.; Blewett, J.; Camill, P.; Charman, D.J.; et al. Expert assessment of future vulnerability of the global peatland carbon sink. Nat. Clim. Chang. 2021, 11, 70-77. [CrossRef] 
38. Hilasvuori, E.; Akujärvi, A.; Fritze, H.; Karhu, K.; Laiho, R.; Mäkiranta, P.; Oinonen, M.; Palonen, V.; Vanhala, P.; Liski, J. Temperature sensitivity of decomposition in a peat profile. Soil Biol. Biochem. 2013, 67, 47-54. [CrossRef]

39. Soil Survey Staff. Keys to Soil Taxonomy, 12th ed.; Natural Resources Conservation Service: Washington, DC, USA, 2014; pp. 167-172.

40. Subardja, D.; Ritung, S.; Anda, M.; Sukarman, E.S.; Subandiono, R.E. Petunjuk Teknis Klasifikasi Tanah Nasional, Edisi ke-2.: Balai Besar Penelitian dan Pengembangan Sumberdaya Lahan Pertanian, Badan Penelitian dan Pengembangan Pertanian; Balai Penelitian Tanah: Bogor, Indonesia, 2014.

41. Horák-Terra, I.; Cortizas, A.M.; de Camargo, P.B.; Silva, A.C.; Vidal-Torrado, P. Characterization of properties and main processes related to the genesis and evolution of tropical mountain mires from Serra do Espinhaço Meridional, Minas Gerais, Brazil. Geoderma 2014, 232-234, 183-197. [CrossRef]

42. Könönen, M.; Jauhiainen, J.; Laiho, R.; Kusin, K.; Vasander, H. Physical and chemical properties of tropical peat under stabilised land uses. Mires Peat 2015, 16, 1-13.

43. Anshari, G.; Afifudin, M.; Nuriman, M.; Gusmayanti, E.; Arianie, L.; Susana, R.; Nusantara, R.W.; Sugardjito, J.; Rafiastanto, A. Drainage and land use impacts on changes in selected peat properties and peat degradation in West Kalimantan Province, Indonesia. Biogeosciences 2010, 7, 3403-3419. [CrossRef]

44. Murtilakso, K.; Sabiham, S.; Sutandi, A.; Sutarta, E.S. Hydrophobicity of Tropical Peat Soil from an Oil Palm Plantation in North Sumatra. J. Agron. 2016, 15, 114-121. [CrossRef]

45. Sangok, F.E.; Maie, N.; Melling, L.; Watanabe, A. Evaluation on the decomposability of tropical forest peat soils after conversion to an oil palm plantation. Sci. Total. Environ. 2017, 587-588, 381-388. [CrossRef]

46. Warren, M.W.; Kauffman, J.B.; Murdiyarso, D.; Anshari, G.; Hergoualc’h, K.; Kurnianto, S.; Purbopuspito, J.; Gusmayanti, E.; Afifudin, M.; Rahajoe, J.; et al. A cost-efficient method to assess carbon stocks in tropical peat soil. Biogeosciences 2012, 9, 4477-4485. [CrossRef]

47. Nurulita, Y.; Adetutu, E.M.; Kadali, K.K.; Zul, D.; Mansur, A.A.; Ball, A.S. The assessment of the impact of oil palm and rubber plantations on the biotic and abiotic properties of tropical peat swamp soil in Indonesia. Int. J. Agric. Sustain. 2015, 13, 150-166. [CrossRef]

48. Tonks, A.J.; Aplin, P.; Beriro, D.J.; Cooper, H.; Evers, S.; Vane, C.H.; Sjögersten, S. Impacts of conversion of tropical peat swamp forest to oil palm plantation on peat organic chemistry, physical properties and carbon stocks. Geoderma 2017, $289,36-45$. [CrossRef]

49. Rixen, T.; Baum, A.; Wit, F.; Samiaji, J. Carbon Leaching from Tropical Peat Soils and Consequences for Carbon Balances. Front. Earth Sci. 2016, 4. [CrossRef]

50. Muller, D.N.; Warneke, T.; Rixen, T.; Muller, M.; Jamahari, S.; Denis, N.; Mujahid, A.; Notholt, J. Lateral carbon fluxes and CO 2 outgassing from a tropical peat-draining river. Biogeosciences 2015, 12, 5967-5979. [CrossRef]

51. Gandois, L.; Teisserenc, R.; Cobb, A.; Chieng, H.; Lim, L.; Kamariah, A.; Hoyt, A.; Harvey, C. Origin, composition, and transformation of dissolved organic matter in tropical peatlands. Geochim. Cosmochim. Acta 2014, 137, 35-47. [CrossRef]

52. Gandois, L.; Hoyt, A.M.; Mounier, S.; Le Roux, G.; Harvey, C.F.; Claustres, A.; Nuriman, M.; Anshari, G. From canals to the coast: Dissolved organic matter and trace metal composition in rivers draining degraded tropical peatlands in Indonesia. Biogeosciences 2020, 17, 1897-1909. [CrossRef]

53. Anshari, G.Z. Circularity and Singularity of Tropical Peat Swamp Forest Ecosystems. In Tropical Peatland Eco-Management; Osaki, M., Tsuji, N., Rieley, J., Foead, N., Eds.; Springer: Tokyo, Japan, 2021.

54. Yule, C.M.; Lim, Y.Y.; Lim, T.Y. Recycling of phenolic compounds in Borneo's tropical peat swamp forests. Carbon Balance Manag. 2018, 13, 3. [CrossRef] [PubMed]

55. Yule, C.M.; Lim, Y.Y.; Lim, T.Y. Degradation of Tropical Malaysian Peatlands Decreases Levels of Phenolics in Soil and in Leaves of Macaranga pruinosa. Front. Earth Sci. 2016, 4. [CrossRef]

56. Wakhid, N.; Hirano, T.; Okimoto, Y.; Nurzakiah, S.; Nursyamsi, D. Soil carbon dioxide emissions from a rubber plantation on tropical peat. Sci. Total. Environ. 2017, 581-582, 857-865. [CrossRef] [PubMed]

57. Hooijer, A.; Silvius, M.; Wosten, H.; Page, S. PEAT-CO2, Assessment of CO2 Emissions from Drained Peatland in SE Asia; Delft Hydraulic: Delft, The Netherlands, 2006.

58. Wösten, J.H.M.; Ritzema, H.P. Land and water management options for peatland development in Sarawak. Int. Peat J. 2015, 11, 59-66.

59. Wösten, J.; Clymans, E.; Page, S.; Rieley, J.; Limin, S. Peat-water interrelationships in a tropical peatland ecosystem in Southeast Asia. Catena 2008, 73, 212-224. [CrossRef]

60. Stephens, J.C. Peat and muck drainage problems. J. Irrig. Drain. Div. 1969, 2, 285-305. [CrossRef]

61. Ishikura, K.; Hirano, T.; Okimoto, Y.; Hirata, R.; Kiew, F.; Melling, L.; Aeries, E.B.; Lo, K.S.; Musin, K.K.; Waili, J.W.; et al. Soil carbon dioxide emissions due to oxidative peat decomposition in an oil palm plantation on tropical peat. Agric. Ecosyst. Environ. 2018, 254, 202-212. [CrossRef]

62. Miettinen, J.; Hooijer, A.; Vernimmen, R.; Liew, S.C.; Page, S.E. From carbon sink to carbon source: Extensive peat oxidation in insular Southeast Asia since 1990. Environ. Res. Lett. 2017, 12, 024014. [CrossRef]

63. Hoyt, A.M.; Chaussard, E.; Seppalainen, S.S.; Harvey, C.F. Widespread subsidence and carbon emissions across Southeast Asian peatlands. Nat. Geosci. 2020, 13, 435-440. [CrossRef] 
64. Evans, C.D.; Williamson, J.M.; Kacaribu, F.; Irawan, D.; Suardiwerianto, Y.; Hidayat, M.F.; Laurén, A.; Page, S.E. Rates and spatial variability of peat subsidence in Acacia plantation and forest landscapes in Sumatra, Indonesia. Geoderma 2019, 338, 410-421. [CrossRef]

65. Joosten, H.; Clarke, D. Wise Use of Mires and Peatlands; International Mire Conservation Group and International Peat Society: Devon, UK, 2002.

66. Khakim, M.Y.N.; Bama, A.A.; Yustian, I.; Poerwono, P.; Tsuji, T.; Matsuoka, T. Peatland subsidence and vegetation cover degradation as impacts of the 2015 El niño event revealed by Sentinel-1A SAR data. Int. J. Appl. Earth Obs. Geoinf. 2020, 84, 101953. [CrossRef]

67. Darmawan, S.M.; Putro, D.; Baskoro, T.; Nugroho, B. Indications of Compaction in Relation To Subsidence on Peatlands, in Peat in balance. In Proceedings of the 14th International Peat Congress, Stockholm, Sweden, 3-8 June 2012; pp. 115-123.

68. Kool, D.M.; Buurman, P.; Hoekman, D.H. Oxidation and compaction of a collapsed peat dome in Central Kalimantan. Geoderma 2006, 137, 217-225. [CrossRef]

69. Carlson, K.M.; Goodman, L.K.; May-Tobin, C.C. Modeling relationships between water table depth and peat soil carbon loss in Southeast Asian plantations. Environ. Res. Lett. 2015, 10, 074006. [CrossRef]

70. IPCC. 2013 Supplement to the 2006 IPCC Guidelines for National Greenhouse Gas Inventories: Wetlands Task Force on National Greenhouse Gas Inventories; IPCC: Geneva, Switzerland, 2014.

71. Jamaludin, J.; Gusmayanti, E.; Anshari, G.Z. Emisi Karbon Dioksida (CO2) dari Pertanian Skala Kecil di Lahan Gambut. J. Ilmu Lingkung. 2020, 18, 582-588. [CrossRef]

72. Khasanah, N.; Van Noordwijk, M. Subsidence and carbon dioxide emissions in a smallholder peatland mosaic in Sumatra, Indonesia. Mitig. Adapt. Strat. Glob. Chang. 2019, 24, 147-163. [CrossRef]

73. Leifeld, J.; Steffens, M.; Galego-Sala, A. Sensitivity of peatland carbon loss to organic matter quality. Geophys. Res. Lett. 2012, 39, 1-6. [CrossRef]

74. Girkin, N.T.; Vane, C.H.; Cooper, H.V.; Moss-Hayes, V.; Craigon, J.; Turner, B.L.; Ostle, N.; Sjögersten, S. Spatial variability of organic matter properties determines methane fluxes in a tropical forested peatland. Biogeochemistry 2019, 142, 231-245. [CrossRef]

75. Minick, K.J.; Kelley, A.M.; Miao, G.; Li, X.; Noormets, A.; Mitra, B.; King, J.S. Microtopography Alters Hydrology, Phenol Oxidase Activity and Nutrient Availability in Organic Soils of a Coastal Freshwater Forested Wetland. Wetlands 2018, 39, 263-273. [CrossRef]

76. Jauhiainen, J.; Takahashi, H.; Heikkinen, J.E.P.; Martikainen, P.J.; Vasander, H. Carbon fluxes from a tropical peat swamp forest floor. Glob. Chang. Biol. 2005, 11, 1788-1797. [CrossRef]

77. Lilleskov, E.; McCullough, K.; Hergoualc'h, K.; Torres, D.D.C.; Chimner, R.; Murdiyarso, D.; Kolka, R.; Bourgeau-Chavez, L.; Hribljan, J.; Pasquel, J.D.A.; et al. Is Indonesian peatland loss a cautionary tale for Peru? A two-country comparison of the magnitude and causes of tropical peatland degradation. Mitig. Adapt. Strat. Glob. Chang. 2019, 24, 591-623. [CrossRef]

78. Kareksela, S.; Haapalehto, T.; Juutinen, R.; Matilainen, R.; Tahvanainen, T.; Kotiaho, J.S. Fighting carbon loss of degraded peatlands by jump-starting ecosystem functioning with ecological restoration. Sci. Total Environ. 2015, 537, 268-276. [CrossRef] [PubMed]

79. Murdiyarso, D.; Hergoualc'h, K.; Verchot, L.V. Opportunities for reducing greenhouse gas emissions in tropical peatlands. Proc. Natl. Acad. Sci. USA 2010, 107, 19655-19660. [CrossRef]

80. Loisel, J.; Yu, Z.; Beilman, D.W.; Camill, P.; Alm, J.; Amesbury, M.J.; Anderson, D.; Andersson, S.; Bochicchio, C.; Barber, K.; et al. A database and synthesis of northern peatland soil properties and Holocene carbon and nitrogen accumulation. Holocene 2014, 24, 1028-1042. [CrossRef]

81. Hanson, P.J.; Griffiths, N.A.; Iversen, C.M.; Norby, R.J.; Sebestyen, S.D.; Phillips, J.R.; Chanton, J.P.; Kolka, R.K.; Malhotra, A.; Oleheiser, K.C.; et al. Rapid Net Carbon Loss From a Whole-Ecosystem Warmed Peatland. AGU Adv. 2020, 1, 1-18. [CrossRef]

82. Wilson, R.M.; Hopple, A.M.; Tfaily, M.M.; Sebestyen, S.; Schadt, C.W.; Pfeifer-Meister, L.; Medvedeff, C.; McFarlane, K.J.; Kostka, J.E.; Kolton, M.; et al. Stability of peatland carbon to rising temperatures. Nat. Commun. 2016, 7, 13723. [CrossRef]

83. Yu, Z.; Loisel, J.; Turetsky, M.R.; Cai, S.; Zhao, Y.; Frolking, S.; Macdonald, G.M.; Bubier, J.L. Evidence for elevated emissions from high-latitude wetlands contributing to high atmospheric $\mathrm{CH} 4$ concentration in the early Holocene. Glob. Biogeochem. Cycles 2013, 27, 131-140. [CrossRef]

84. Ishikura, K.; Yamada, H.; Toma, Y.; Takakai, F.; Morishita, T.; Darung, U.; Limin, A.; Limin, S.H.; Hatano, R. Effect of groundwater level fluctuation on soil respiration rate of tropical peatland in Central Kalimantan, Indonesia. Soil Sci. Plant Nutr. 2016, 63, 1-13. [CrossRef]

85. Konecny, K.; Ballhorn, U.; Navratil, P.; Jubanski, J.; Page, S.E.; Tansey, K.; Hooijer, A.; Vernimmen, R.; Siegert, F. Variable carbon losses from recurrent fires in drained tropical peatlands. Glob. Chang. Biol. 2016, 22, 1469-1480. [CrossRef]

86. Astiani, D.; Curran, L.; Burhanuddin; Taherzadeh, M.; Mujiman; Hatta, M.; Pamungkas, W.; Gusmayanti, E. Fire-driven biomass and peat carbon losses and post-fire soil co2 emission in a west Kalimantan Peatland Forest. J. Trop. For. Sci. 2018, 30, 570-575. [CrossRef]

87. Lupascu, M.; Akhtar, H.; Smith, T.E.L.; Sukri, R.S. Post-Fire Carbon Emissions from Degraded Tropical Peat Swamp Forests in Brunei, EGU General Assembly. 2020. Available online: https:/ / meetingorganizer.copernicus.org/EGU2020/EGU2020-6337.html (accessed on 22 May 2020). 
88. Hooijer, A.; Page, S.; Canadell, J.; Silvius, M.; Kwadijk, J.; Wösten, H.; Jauhiainen, J. Current and future CO2 emissions from drained peatlands in Southeast Asia. Biogeosciences 2010, 7, 1505-1514. [CrossRef]

89. Cooper, H.V.; Vane, C.H.; Evers, S.; Aplin, P.; Girkin, N.T.; Sjögersten, S. From peat swamp forest to oil palm plantations: The stability of tropical peatland carbon. Geoderma 2019, 342, 109-117. [CrossRef]

90. Itoh, M.; Okimoto, Y.; Hirano, T.; Kusin, K. Factors affecting oxidative peat decomposition due to land use in tropical peat swamp forests in Indonesia. Sci. Total. Environ. 2017, 609, 906-915. [CrossRef]

91. Evers, S.; Yule, C.M.; Padfield, R.; O’Reilly, P.; Varkkey, H. Keep wetlands wet: The myth of sustainable development of tropical peatlands-Implications for policies and management. Glob. Chang. Biol. 2017, 23, 534-549. [CrossRef]

92. Joosten, H.; Tapio-Biström, M.-L.; Tol, S. Peatlands-Guidance for Climate Change Mitigation through Conservation, Rehabilitation and Sustainable Use; Food and Agriculture Organization of the United Nations: Rome, Italy, 2012.

93. Günther, A.; Barthelmes, A.; Huth, V.; Joosten, H.; Jurasinski, G.; Koebsch, F.; Couwenberg, J. Prompt rewetting of drained peatlands reduces climate warming despite methane emissions. Nat. Commun. 2020, 11, 1-5. [CrossRef] [PubMed]

94. Adhi, Y.A.; Anwar, S.; Tarigan, S.D.; Sahari, B. Relationship between groundwater level and water content in oil palm plantation on drained peatland in Siak, Riau Province, Indonesia, Pertanika. J. Trop. Agric. Sci. 2020, 43, 45-427.

95. Novita, N. Carbon Stocks and Soil Greenhouse Gas Emissions Associated with Forest Conversion to Oil Palm Plantations in Tanjung Puting Tropical Peatlands, Indonesia; Oregon State University: Corvallis, OR, USA, 2016.

96. Dadap, N.C.; Hoyt, A.M.; Cobb, A.R.; Oner, D.; Kozinski, M.; Fua, P.V.; Rao, K.; Harvey, C.F.; Konings, A.G. Drainage Canals in Southeast Asian Peatlands Increase Carbon Emissions. AGU Adv. 2021, 2, 1-14. [CrossRef]

97. Hooijer, A.; Vernimmen, R.; Mawdsley, N.; Page, S.; Mulyadi, D.; Visser, M. Assessment of Impacts of Plantation Drainage on the Kampar Peninsula Peatland, Riau; Wetlands International: Amsterdam, The Netherlands, 2015.

98. Maswar, M. Kajian Cadangan Karbon Pada Lahan Gambut Tropical Yang Didrainase Untuk Tanaman Tahunan. Ph.D. Thesis, Bogor Agricultural University, Bogor, Indonesia, 2011.

99. Evans, C.D.; Callaghan, N.; Jaya, A.; Grinham, A.; Sjogersten, S.; Page, S.E.; Harrison, M.E.; Kusin, K.; Kho, L.K.; Ledger, M.; et al. A Novel Low-Cost, High-Resolution Camera System for Measuring Peat Subsidence and Water Table Dynamics. Front. Environ. Sci. 2021, 9, 1-18. [CrossRef]

100. Drexler, J.Z.; De Fontaine, C.S.; Deverel, S.J. The legacy of wetland drainage on the remaining peat in the Sacramento-San Joaquin Delta, California, USA. Wetlands 2009, 29, 372-386. [CrossRef]

101. Erkens, G.; Van Der Meulen, M.J.; Middelkoop, H. Double trouble: Subsidence and CO2 respiration due to 1,000 years of Dutch coastal peatlands cultivation. Hydrogeol. J. 2016, 24, 551-568. [CrossRef]

102. Gora, E.M.; Lucas, J.M.; Yanoviak, S.P. Microbial Composition and Wood Decomposition Rates Vary with Microclimate from the Ground to the Canopy in a Tropical Forest. Ecosystems 2019, 22, 1206-1219. [CrossRef]

103. Neller, J.R. Oxidation loss of Lowmoor peat in fields with different water tables. Soil Sci. 1944, 58, 195-204. [CrossRef]

104. Fenner, N.; Freeman, C. Drought-induced carbon loss in peatlands. Nat. Geosci. 2011, 4, 895-900. [CrossRef]

105. Freeman, C.; Ostle, N.; Fenner, N.; Kang, H. A regulatory role for phenol oxidase during decomposition in peatlands. Soil Biol. Biochem. 2004, 36, 1663-1667. [CrossRef]

106. Kleber, M. What is recalcitrant soil organic matter? Environ. Chem. 2010, 7, 320-332. [CrossRef] 